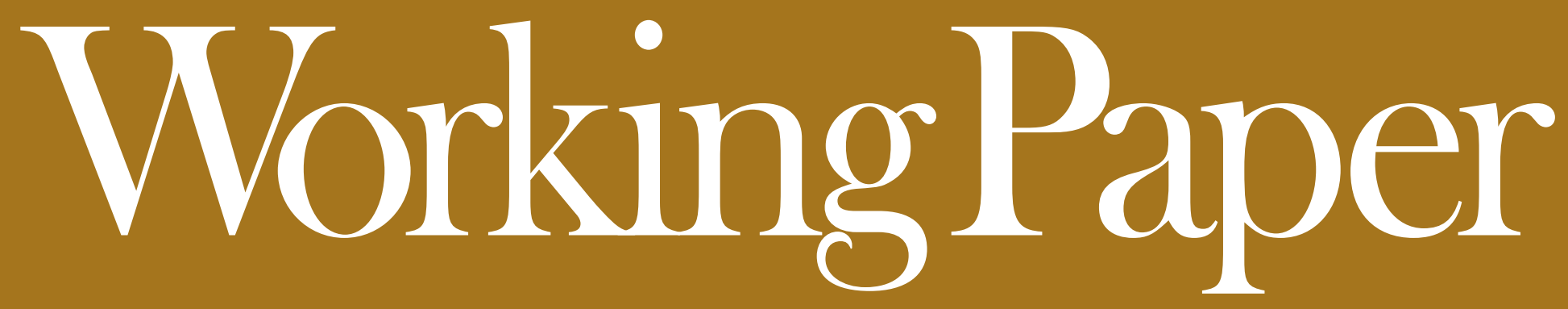

No. 129. September 2013

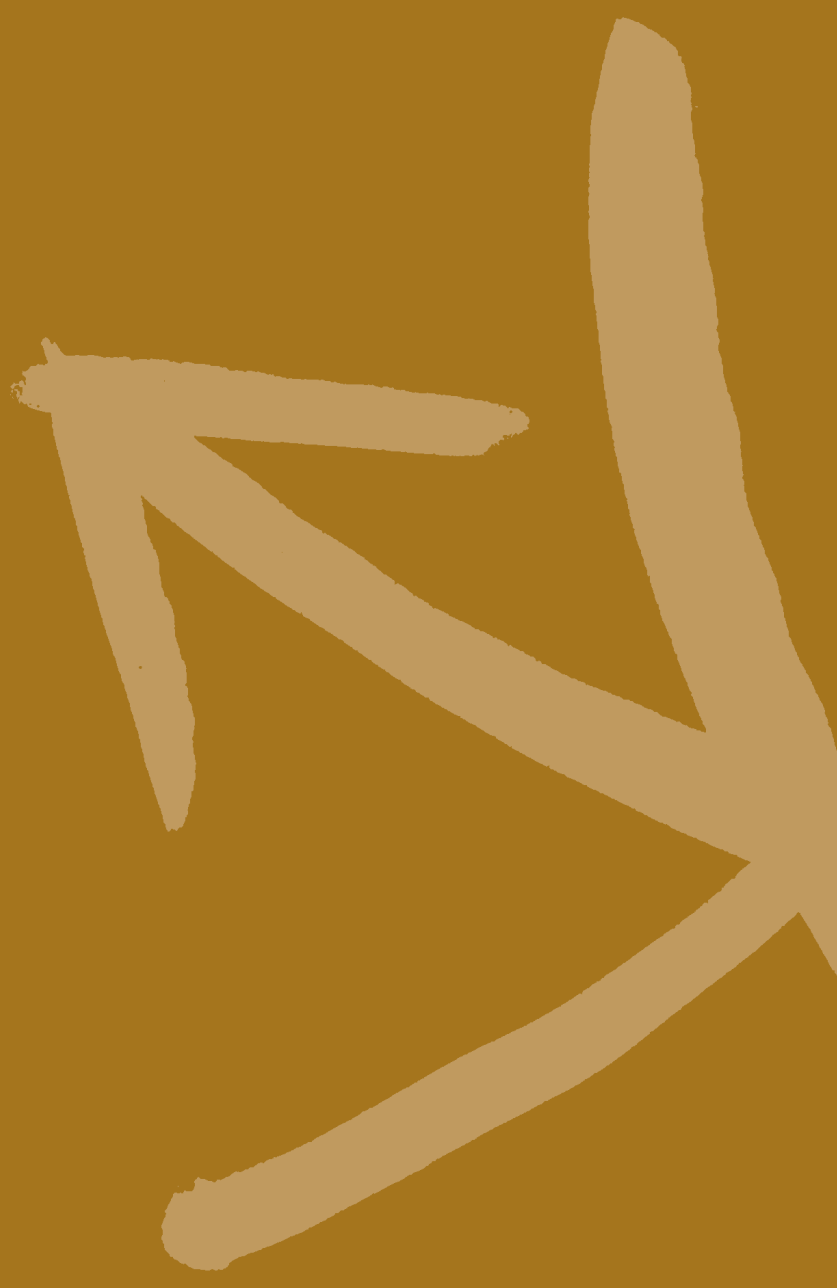

On the Usefulness of

Constant Gain Least Squares

when Forecasting the

Unemployment Rate

By Jan-Erik Antipin, Jimmy Boumediene and Pär Österholm

National Institute of Economic Research

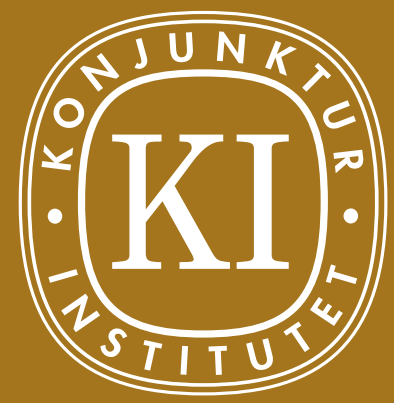





\title{
On the Usefulness of Constant Gain Least Squares when Forecasting the Unemployment Rate*
}

\author{
Jan-Erik Antipin ${ }^{\#}$ \\ Farid Jimmy Boumediene $e^{\forall}$
}

Pär Österholm*

\footnotetext{
* We are grateful to seminar participants at the National Institute of Economic Research for valuable comments.

\# Finnish Tax Administration, P.O. Box 325, 00052 VERO, Finland e-mail: jan-erik.antipin@vero.fi Phone: +358 406684931

${ }^{\forall}$ Confederation of Swedish Enterprise, Storgatan 19, 11482 Stockholm, Sweden email: jimmy.boumediene@svensktnaringsliv.se Phone: +46703456041

* National Institute of Economic Research, Box 3116, 10362 Stockholm, Sweden e-mail: par.osterholm@konj.se Phone: +4684535948

WORKING PAPER NO 129, SEPTEMBER 2013 
NIER prepares analyses and forecasts of the Swedish and international economy and conducts related research. NIER is a government agency accountable to the Ministry of Finance and is financed largely by Swedish government funds. Like other government agencies, NIER has an independent status and is responsible for the assessments that it publishes.

The Working Paper series consists of publications of research reports and other detailed analyses. The reports may concern macroeconomic issues related to the forecasts of the institute, research in environmental economics, or problems of economic and statistical methods. Some of these reports are published in their final form in this series, whereas others are previews of articles that are subsequently published in international scholarly journals under the heading of Reprints. Reports in both of these series can be ordered free of charge. Most publications can also be downloaded directly from the NIER home page. 


\begin{abstract}
In this paper, we assess the usefulness of constant gain least squares (CGLS) when forecasting the unemployment rate. Using quarterly data from 1970 to 2009, we conduct an out-of-sample forecast exercise in which univariate autoregressive models for the unemployment rate in Australia, Sweden, the United Kingdom and the United States are employed. Results show that CGLS very rarely outperforms OLS. At horizons of six to eight quarters, OLS is always associated with higher forecast precision, regardless of model size or gain employed for Australia, Sweden and the United States. Our findings suggest that while CGLS has been shown valuable when forecasting certain macroeconomic time series, it has shortcomings when forecasting the unemployment rate. One problematic feature is found to be an increased tendency for the autoregressive model to have explosive dynamics when estimated with
\end{abstract} CGLS.

JEL Classification: E24, E27

Keywords: Out-of-sample forecasts 


\section{Summary in Swedish}

I denna studie jämförs prognosförmågan hos univariata autoregressiva modeller skattade med två olika metoder: ordinary least squares (OLS) och constant gain least squares (CGLS). Vi utvärderar modellprognoser för arbetslöshetsgraden i Australien, Storbritannien, Sverige och USA. Resultaten visar att CGLS väldigt sällan genererar bättre prognoser än OLS. På prognoshorisonter från sex till åtta kvartal förknippas OLS alltid med en högre prognosprecision än CGLS oavsett modellens storlek eller vilket gain som används för Australien, Sverige och USA. Resultaten antyder att trots att CGLS har visat sig värdefullt när det gäller att prognostisera vissa makroekonomiska tidsserier så förefaller det finnas problem när arbetslöshetsgraden skall prognostiseras. Ett av dessa problem är en ökad tendens för den autoregressiva modellen att ha explosiv dynamik när den skattas med CGLS. 


\section{Contents}

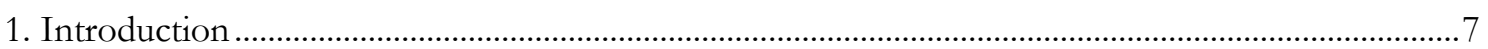

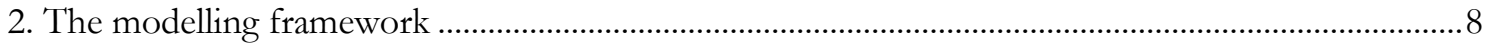

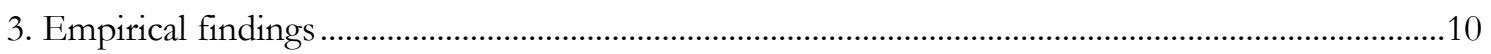

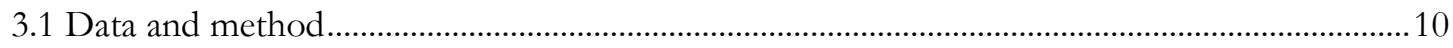

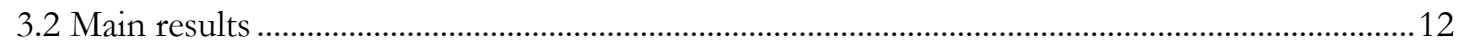

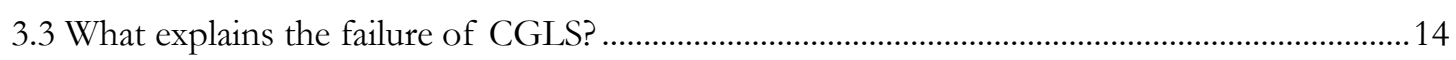

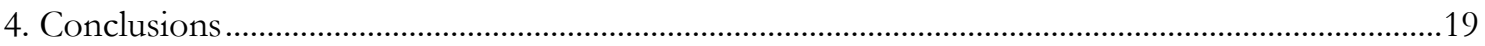

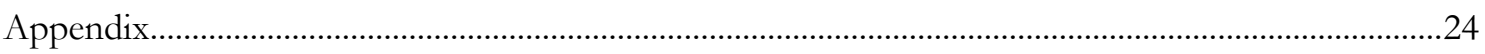





\section{Introduction}

Constant gain least squares (CGLS) has become increasingly popular in macroeconomic models where the rational-expectations framework has been abandoned; see for example Sargent (1999), Evans and Honkapohja (2001), Orphanides and Williams (2004), Gaspar et al. (2006) and Dale et al. (2011). In such models, agents in the economy update their beliefs about the economy's true parameter values each period as additional data become available. CGLS attaches a smaller weight to an observation the more time has passed since its occurrence. As such, it allows for the possibility of structural change. However, while being a popular estimation method for forecasting models in theoretical frameworks, the empirical literature employing CGLS in forecasting is limited. Nevertheless, analysis by Branch and Evans (2006) shows that the use of CGLS can be fruitful when forecasting inflation and GDP growth using low-order vector autoregressions (VARs). In addition, Antipin et al. (2012) show that CGLS is useful when forecasting inflation in Australia, Sweden, the United Kingdom and the United States using univariate autoregressive (AR) models.

The infrequent use of CGLS in the empirical forecasting literature is surprising, particularly given the potential for CGLS to account for structural change through the explicit use of time-varying coefficients. Many forecasters, policy makers and analysts are interested in forecasting variables where there is reason to believe that the time-series properties are changing over time. One such variable is the unemployment rate. Due to the social consequences of unemployment, politicians and policy institutions in many countries subject the labour market to what can be seen as a reasonably steady flow of policy experiments. For example, in Australia, a set of labour-market programs known as "Working nation" was introduced in 1994. This included intensive counselling services and a job-creation program for long-term unemployed. However, with a shift of government in 1996, the program was abolished. ${ }^{1}$ In Sweden, "Youth practice" - a subsidised work program for young unemployed - was introduced in 1992 due to the rapidly rising unemployment rate at the time. In 1995, it was replaced by other programs.2 Finally, in the United States, the duration of unemployment benefits are regularly extended during recessions. In addition to policy changes, there are also other aspects of the labour market that might be subject to change, such as the degree of centralization in the wage-bargaining process. ${ }^{3}$ In light of such changes, one would expect the level and/or dynamics of the unemployment rate to change over time. ${ }^{4}$ Empirical support for time variation in the dynamics and/or equilibrium level of the unemployment rate has been provided by, for example, Jaeger and Parkinson (1994), Gordon (1997), Debelle and Vickery (1998), Apel and Jans-

\footnotetext{
${ }^{1}$ See, for example, Webster and Harding (2001).

2 See, for example, Larsson (2003).

${ }^{3}$ See, for example, Uusitalo (2005) and Du Caju et al. (2008).

4 One concrete example of this is that the equilibrium unemployment rate should rise when the duration of unemployment benefits is extended; see, for example, Mortensen (1977).
} 
son (1999), Papell et al. (2000), Cogley and Sargent (2001), Skalin and Teräsvirta (2002), Summers (2004), Lim et al. (2009) and Dueker et al. (2010).

When it comes to forecasting the unemployment rate, there is a large literature employing a fairly wide range of methods; see, for example, Funke (1992), Montgomery et al. (1998), Rothman (1998), Brown and Moshiri (2004), Franses et al. (2004), Golan and Perloff (2004), Deschamps (2008) and Milas and Rothman (2008). However, the use of CGLS in unemployment rate forecasting has (to our knowledge) not been investigated previously. The purpose of this paper is therefore to assess the usefulness of CGLS when forecasting the unemployment rate. This will be done by comparing the out-of-sample forecast performance of univariate AR models, specifically i) AR models estimated with OLS and ii) AR models with time-varying parameters estimated by CGLS. This is a reasonable starting point for an investigation of the usefulness of CGLS since AR models estimated with OLS are commonly used in empirical work and are also generally considered to forecast reasonably well. ${ }^{5}$ Out-of-sample forecast exercises are carried out for four different countries, namely Australia, Sweden, the United Kingdom and the United States. Using quarterly data from 1970 to 2009, we find that CGLS largely is unsuccessful in improving forecast precision relative to OLS. The results in this paper hence suggest that while CGLS has theoretical appeal - and also has been shown to be an empirically relevant forecasting tool in certain settings - it does not seem to be a simple and certain way to improve macroeconomic forecasts.

The rest of this paper is organised as follows: Section 2 discusses the models and estimation. In Section 3, data are presented and the results are discussed. Finally, Section 4 concludes.

\section{The modelling framework}

We assess the empirical usefulness of CGLS as a forecasting tool through an out-of-sample forecast exercise. Following Antipin et al. (2012), univariate AR models are employed for this purpose; these are estimated using two different methods, namely CGLS and OLS. Since OLS is the most commonly employed estimation method for AR models in applied work, it serves as a natural benchmark against which to compare CGLS.

There is, however, also good theoretical motivation for comparing these two methods since OLS and CGLS can be seen as having fundamentally different assumptions regarding the underlying structure of the economy. In particular, OLS is a natural choice when estimating an AR model if one believes that there has been no structural change since it relies on the assumption of parameters being constant over time. We accordingly write the $\operatorname{AR}(p)$ model as

\footnotetext{
${ }^{5}$ AR models are accordingly often used as a benchmark in the forecasting literature; see, for example, Pesaran et al. (2009).
} 
$u_{t}=\alpha+\beta_{1} u_{t-1}+\beta_{2} u_{t-2}+\ldots+\beta_{p} u_{t-p}+\varepsilon_{t}$,

where $u_{t}$ is the unemployment rate and $\varepsilon_{t}$ is an iid error term. In contrast, when relying on CGLS as estimation method, time variation of the parameters is explicitly assumed and we write the $\operatorname{AR}(p)$ model as

$u_{t}=\alpha_{t}+\beta_{1, t} u_{t-1}+\beta_{2, t} u_{t-2}+\ldots+\beta_{p, t} u_{t-p}+\varepsilon_{t}$.

Defining the parameter vector as $c_{t}=\left(\begin{array}{lllll}\alpha_{t} & \beta_{1, t} & \beta_{2, t} & \ldots & \beta_{p, t}\end{array}\right)^{\prime}$, the estimated parameter vector is updated according to

$\hat{c}_{t}=\hat{c}_{t-1}+\kappa R_{t}^{-1} X_{t}\left(u_{t}-X_{t}^{\prime} \hat{c}_{t-1}\right)$,

where

$R_{t}=R_{t-1}+\kappa\left(X_{t} X_{t}^{\prime}-R_{t-1}\right)$

where the constant gain is denoted by $\kappa$ and $X_{t}=\left(\begin{array}{lllll}1 & u_{t-1} & u_{t-2} & \ldots & u_{t-p}\end{array}\right)^{\prime}$. The larger $\kappa$ is, the higher is the weight put on more recent observations (which means that parameter estimates are updated faster). The explicitly assumed time variation of the parameters is of course the main reason for our interest in using CGLS in empirical work. If one believes that the structure of the economy is evolving in such a way that there is quantitatively meaningful time variation in the parameters of the AR model, it is reasonable to try to take this into account.

We employ seven different gains for the CGLS algorithm in the out-of-sample forecast exercise in

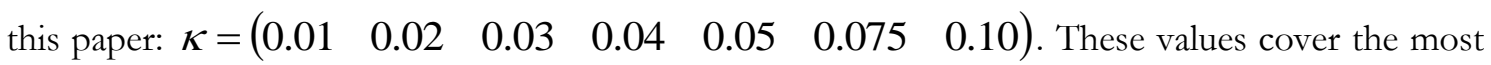
relevant range for the gain used in both the theoretical and the empirical literature. ${ }^{6}$ The initial value of the parameter vector is set to $c=\left(\begin{array}{lllll}0 & 1 & 0 & 0 & \ldots\end{array}\right)^{\prime}$. This is consistent with a univariate random walk without drift, which seems reasonable given that the unemployment rate is often de-

${ }^{6}$ As a comparison, it can be noted that Branch and Evans (2006) found a gain of 0.0345 successful. The results of Antipin et al. (2012) pointed to 0.05 being a reasonable choice. 
scribed as being a unit-root process, or at least highly persistent; 7 see for example León-Ledesma (2002), Camarero and Tamarit (2004) and Gustavsson and Österholm (2007). The initial value for $R$ is set to $R=b b^{\prime}+M$, where $b$ is a $(p+1) \times 1$ vector, $b=\left(\begin{array}{lllll}1 & u_{t-2} & u_{t-3} & \ldots & u_{t-p-1}\end{array}\right)^{\prime} . M$ is a $(p+1) \mathrm{x}(p+1)$ diagonal matrix, $M=\operatorname{diag}\left(\begin{array}{llll}0 & 0.01 & \ldots & 0.01\end{array}\right)$, which is added to $b b^{\prime}$ so that the starting value of $R$ will be non-singular. This way, we get a reasonable starting value for $R .{ }^{8}$

Having briefly presented our modelling framework, we next turn to the issue of out-of-sample forecast performance. While one can hypothesise regarding time-variation in the univariate timeseries representation of unemployment rates, our main objective here is to assess the merit of such an assumption on the forecasting performance of the AR models. In practice, there are of course many ways in which parameters can be time varying and CGLS may not always be able to approximate this well. Hence, it is not necessarily the case that CGLS can generate better forecasts than OLS even if the parameters of the model truly are time varying.

\section{Empirical findings}

\subsection{Data and method}

We use quarterly data on seasonally adjusted unemployment rates for Australia, Sweden, the United Kingdom and the United States from 1970Q1 to 2009Q4. The data are plotted in Figure 1. A noteworthy feature is that while a unique equilibrium level over time in each country certainly cannot be dismissed based solely on a visual inspection, it does not seem unlikely that the unconditional mean changes over time. For example, in Sweden, the unemployment rate fluctuated between 1.8 and 3.7 percent in the 1970s. During the last ten years, on the other hand, it has not dropped below 5.7 percent. Similarly, the UK unemployment rate was substantially higher on average in the 1980s than in the 1970s, with the means for the two decades being 9.9 and 4.6 percent respectively. Figure 1 hence seems to lend some support to the claim made above that the time-series properties of the unemployment rate may be time varying and, accordingly, that CGLS might be of interest from a forecasting perspective. On the other hand, it is also possible that the observed movements are due to a data-generating process which is stable over time but characterised by high persistence.

We conduct the out-of-sample forecast exercise as follows: The parameter values estimated by CGLS are updated according to equations (3) and (4) each quarter and forecasts from one to eight

\footnotetext{
7 These coefficient values are also commonly used as priors in Bayesian analysis of AR and VAR models; see, for example, Litterman (1986) and Beechey and Österholm (2010).

8 Given that our samples all range from 1970Q1 to 2009 Q4 (see the discussion in Section 3), the CGLS estimation is initialised at $t=1971 \mathrm{Q} 2$ to allow for a sufficient number of lags.
} 
quarters ahead are generated at each point in time. The first forecasts are generated in 1983Q1 and the last in 2007Q4. We hence have the same number of forecasts - 100 to be specific - to evaluate for all horizons. The AR model in equation (1) is estimated using OLS on an expanding sample; that is, the model is re-estimated each quarter. ${ }^{9}$ Forecasts from this model are also generated up to eight quarters ahead every quarter from 1983Q1 to 2007Q4. Forecast errors are recorded and used to calculate the root mean square forecast errors (RMSFEs). The RMSFE is defined as

$\operatorname{RMSFE}_{h}=\sqrt{N_{h}^{-1} \sum_{i=0}^{N_{h}-1}\left(u_{t+h+i}-u_{t+h+i \mid t+i}\right)^{2}}$,

where $N_{h}$ is the number of forecasts at horizon $h, u_{t+h}$ is the outcome at time $t+h$ and $u_{t+h \mid t}$ is the forecast of the unemployment rate at time $t+h$ made at time $t$. The RMSFEs of the different models are then compared in order to identify the model that generates the most accurate forecasts.

Figure 1. Unemployment rates.
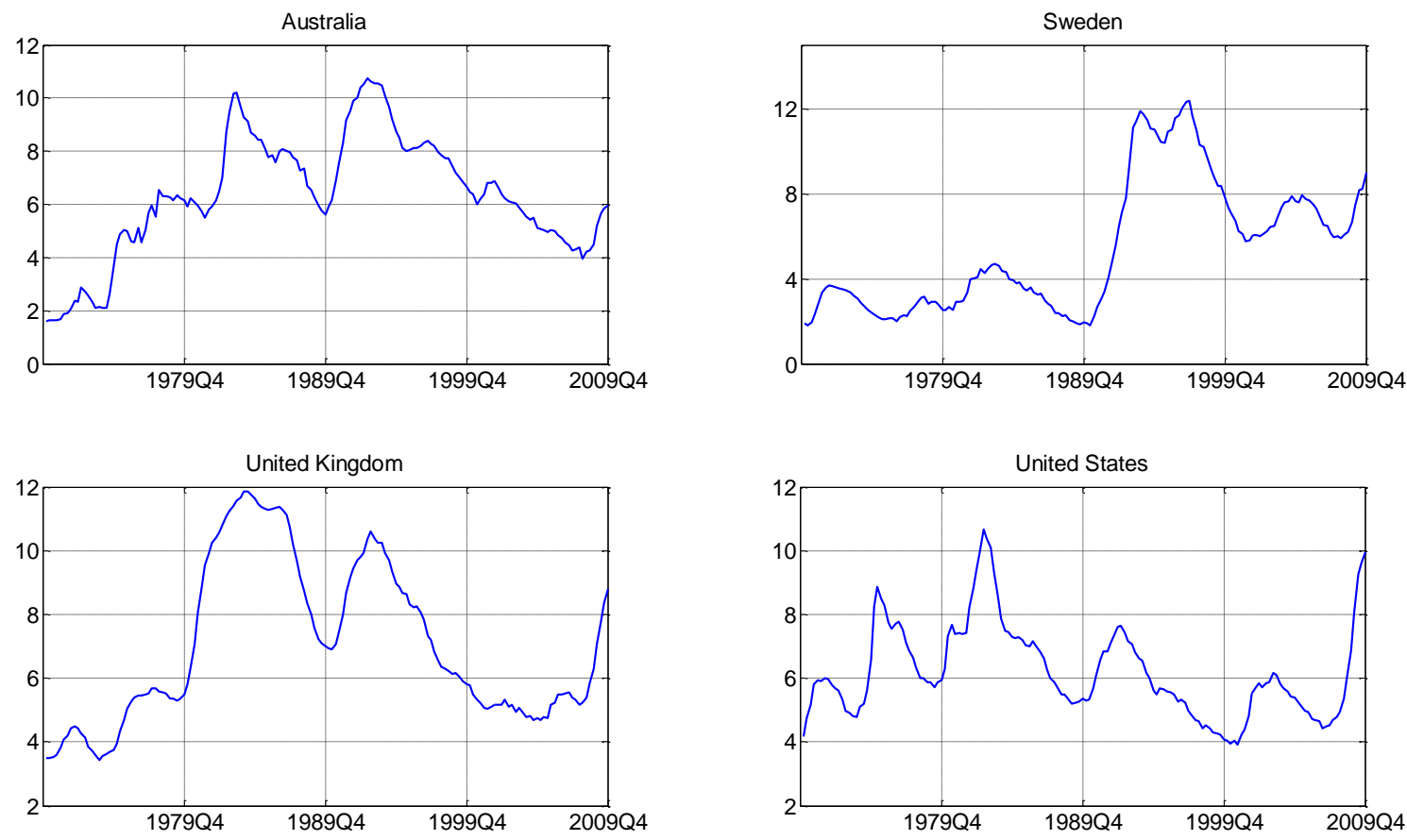

An issue of particular interest to economists doing empirical work is the choice of lag length in AR models. Many approaches have been suggested in the literature and opinions differ concerning the appropriateness of the various alternatives. ${ }^{10}$ We circumvent this issue to a large extent by investi-

\footnotetext{
${ }^{9}$ While the model in equation (1) has constant parameters within each sample, the fact that it is re-estimated each quarter means that there is variation over time in the parameters used to generate the forecasts. This time variation is reasonable though, seeing that the approach mimics how out-of-sample forecasts would be generated in real time.

10 See, for example, Akaike (1974), Schwarz (1978), Hannan and Quinn (1979), Hendry (1995) and Lütkepohl (2007).
} 
gating forecasting performance with respect to all lag lengths, $p=\left(\begin{array}{llll}1 & 2 & 3 & 4\end{array}\right)$; comparisons between OLS and CGLS are then focused on models of a given lag length. As a reference point, we still provide optimal lag length based on the Schwarz (1978) information criterion when applied to equation (1) estimated with OLS. This is done for the initial sample used to estimate the models before the first forecast is generated, that is, 1970Q1 to 1983Q1. This is the most relevant sample for our purposes, since this is the one that would initially be used in practice in real time. Results from this exercise are given in Table 1.

Table 1. Optimal lag length for AR model estimated with OLS.

\begin{tabular}{lc} 
& Lag length \\
\hline Australia & 1 \\
\hline Sweden & 4 \\
United Kingdom & 4 \\
United States & 2
\end{tabular}

Note: Lag length established using the Schwarz (1978) information criterion. Sample periods:1970Q1 to $1983 \mathrm{Q} 1$.

\subsection{Main results}

Concerning the evaluation of the forecasts, we focus solely on the RMSFE and define the best estimation method as the one associated with the lowest RMSFE. ${ }^{11}$ The results from the out-ofsample forecasts are given in Tables A1 to A4 in the Appendix.

Turning first to the results for Australia in Table A1, it can be seen that regardless of lag length, the lowest RMSFEs are almost always obtained when OLS is employed. Only at the one-quarter horizon for the AR(1) model and the one- and two-quarter horizons for the AR(2) model does CGLS offer any kind of improvement over OLS. These improvements are, however, very small - the largest reduction in the RMSFE is three percent. The loss in forecast precision from using CGLS grows with the forecast horizon and tends to be substantial at the longest horizons; at the eight-quarter horizon, CGLS is always at least ten percent worse than OLS. It should also be noted that for large gains, CGLS generates a dramatic loss in forecast precision. For example, at the eight-quarter horizon and using a gain of ten percent, the RMSFE is between 39 and 90 percent larger when CGLS is used. It hence appears that there are virtually no reasons from a forecasting point of view for using CGLS instead of OLS on the Australian data.

Table A2 shows the results for Sweden. Also for Sweden is it - with only a few exceptions - better to use OLS than CGLS. Only at short horizons for the AR(1) model can any improvements from using CGLS be found. At longer horizons, the deterioration in forecasting precision from using CGLS is typically

\footnotetext{
11 No tests for whether differences in forecasting performance are statistically significant are conducted. In line with Armstrong (2007) and Beechey and Österholm (2010), we argue that significance testing is not particularly interesting in the present setting. The performance of two reasonable alternatives is compared and in such a situation few forecasters would choose a model or a method with a larger RMSFE just because it was not significantly larger.
} 
substantial. For example, at the eight-quarter horizon the increase in the RMSFEs for the AR(4) model which was judged optimal according to the Schwarz information critierion - ranges from 16 to 44 percent depending on the gain employed. Furthermore, similar to the results found for Australia, the poor forecasting performance of CGLS at long horizons is particularly evident for large gains. ${ }^{12}$

For the United Kingdom, results are presented in Table A3 and are more favourable to CGLS than what was the case for Australia and Sweden. For example, for the AR(1) model, the RMSFEs are almost exclusively lower for CGLS than OLS (with horizons of five to eight quarters for a gain of 0.01 being the exceptions). It can also be noted that large gains perform unusually well for this model. The AR(1) model is by far the worst in terms of forecasting performance though - its RMSFEs are substantially larger than those of the other models. Hence, it is perhaps more interesting to look at the other models, particularly since the Schwarz information criterion suggests that the AR(4) model is optimal for UK unemployment. For the larger models, it is still the case that CGLS does fairly well at short horizons; the RMSFEs are in many cases lower when CGLS is used than when OLS is used. However, at forecast horizons from six to eight quarters, OLS always outperforms CGLS for the AR(2), AR(3) and AR(4) models. However, the loss in forecasting precision at long horizons from using CGLS is not as large as it was for Australia or Sweden - the RMSFE is never more than 24 percent larger for CGLS.

The results for the United States are given in Table A4. As can be seen, OLS has a lower RMSFE than CGLS in almost all cases. Only when a low gain is used to forecast at short horizons using the AR(1) model is CGLS associated with a lower RMSFE than CGLS. For the AR(3) and AR(4) models, we once again find larger gains associated with a very large deterioration in forecast precision at longer horizons. For both the AR(3) and AR(4) models, the RMSFE at the eight-quarter horizon increases by approximately 85 percent when CGLS with a gain of 0.10 is employed instead of OLS.

The general inability of CGLS to outperform OLS is also exemplified in Figure 2 where we present a selection of relative RMSFEs for the $\operatorname{AR}(p)$ models given in Table 1. The relative RMSFE at horizon $b$ is calculated as

$$
R R_{h}=\frac{R M S F E_{C G L S, h}}{R M S F E_{O L S, h}},
$$

where $R M S F E_{C G L S, h}$ is the RMSFE of the AR model estimated with CGLS at horizon $h$ and $R M S F E_{O L S, h}$ is the corresponding-horizon RMSFE for the AR model estimated with OLS. A

\footnotetext{
12 It can be noted that the RMSFEs for Sweden are substantially larger than those for the other countries. The reason for this is some very large forecast errors at a few timepoints where the estimated models are associated with explosive dynamics (that is, where the sum of the AR coefficients is larger than unity).
} 
relative RMSFE smaller than unity hence means that CGLS is associated with higher forecast precision than OLS; as can be seen from Figure 2, this is rarely the case.

Figure 2. Relative RMSFEs for out-of-sample forecasts generated 1983Q1-2007Q4.
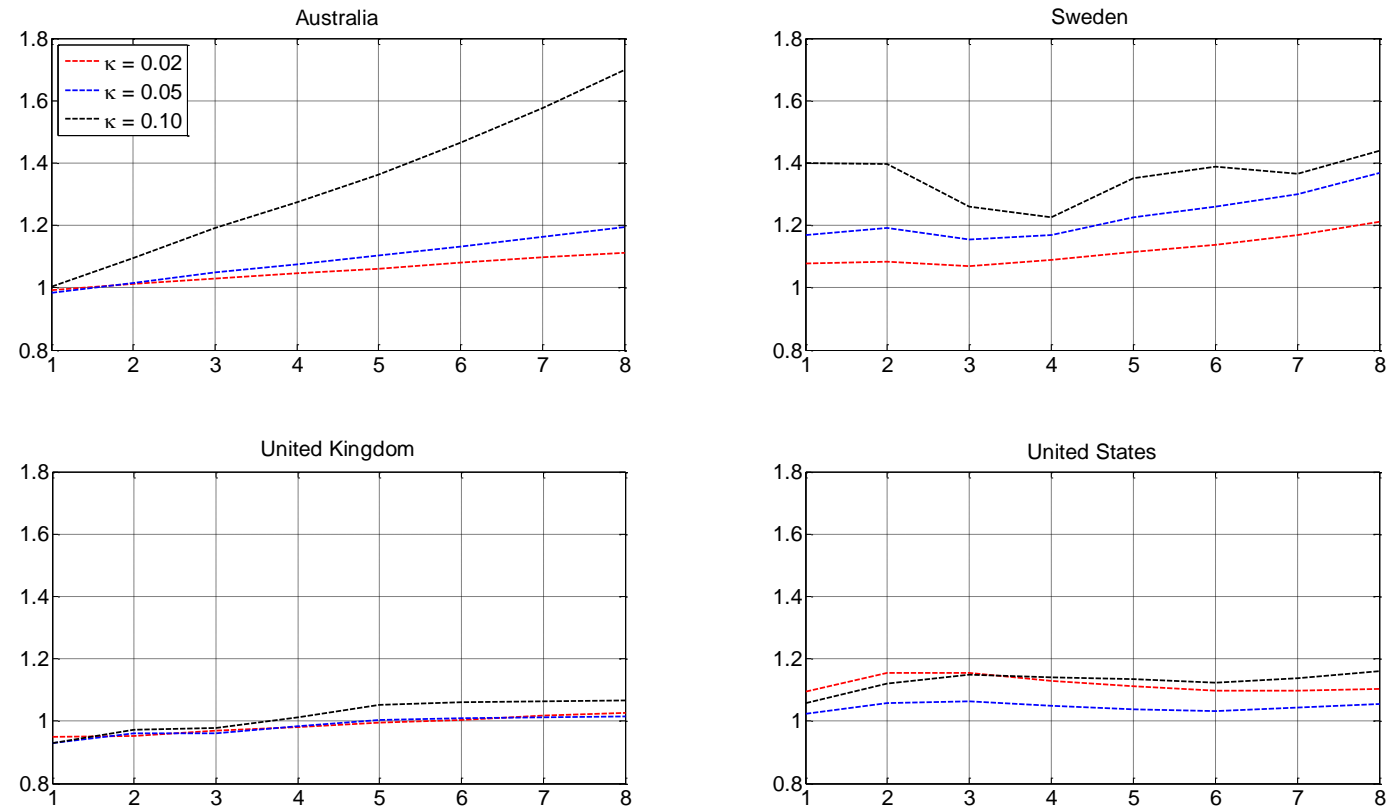

Note: Forecast horizon in quarters on the horizontal axis and relative RMSFE on the vertical. A relative RMSFE smaller than unity indicates that CGLS generates better forecasts than OLS. Lag length used for the respective country is given in Table 1.

\subsection{What explains the failure of CGLS?}

Summing up the results, it can be concluded that CGLS in general does not offer an improvement on the forecast accuracy of OLS on the unemployment data considered here. This might seem both surprising and disappointing given the reliable improvements in forecasting precision documented by Antipin et al. (2012) when forecasting inflation in the same four countries. So what might explain the poor performance of CGLS? As suggested earlier, CGLS should be superior to OLS if there is quantitatively meaningful time variation in the univariate time-series representation. One interpretation of the results from our out-of-sample forecast exercise is accordingly that the data-generating process - despite the fairly extensive literature documenting the opposite - has been reasonably stable.13

This hypothesis finds some support in the data. Figures 3 and 4 show recursive coefficient estimates from two AR(1) models estimated with OLS - one for Australian inflation and one for the

\footnotetext{
13 Alternatively, it could be argued that the time series studied are subject to time variation in parameters that CGLS is not able to approximate well.
} 
Australian unemployment rate. ${ }^{14}$ As pointed out above, the AR(1) model for the Australian unemployment rate did generally forecast a fair bit better when estimated with OLS rather than CGLS. As shown by Antipin et al. (2012) though, the AR(1) model for inflation generated better forecasts when CGLS was used, regardless of the gain employed. Looking at Figure 3, the recursive estimates are moving around substantially over time, indicating that the data-generating process for Australian inflation is not stable. Turning to Figure 4, on the other hand, it can be seen that the recursive estimates are reasonably stable over time for the unemployment rate. This suggests that the datagenerating process for the Australian unemployment rate might be fairly stable, which could help explain why CGLS does not offer improvements in forecast precision relative to OLS in this case.

Figure 3. Recursively estimated coefficients using OLS for AR(1) model for Australian inflation.
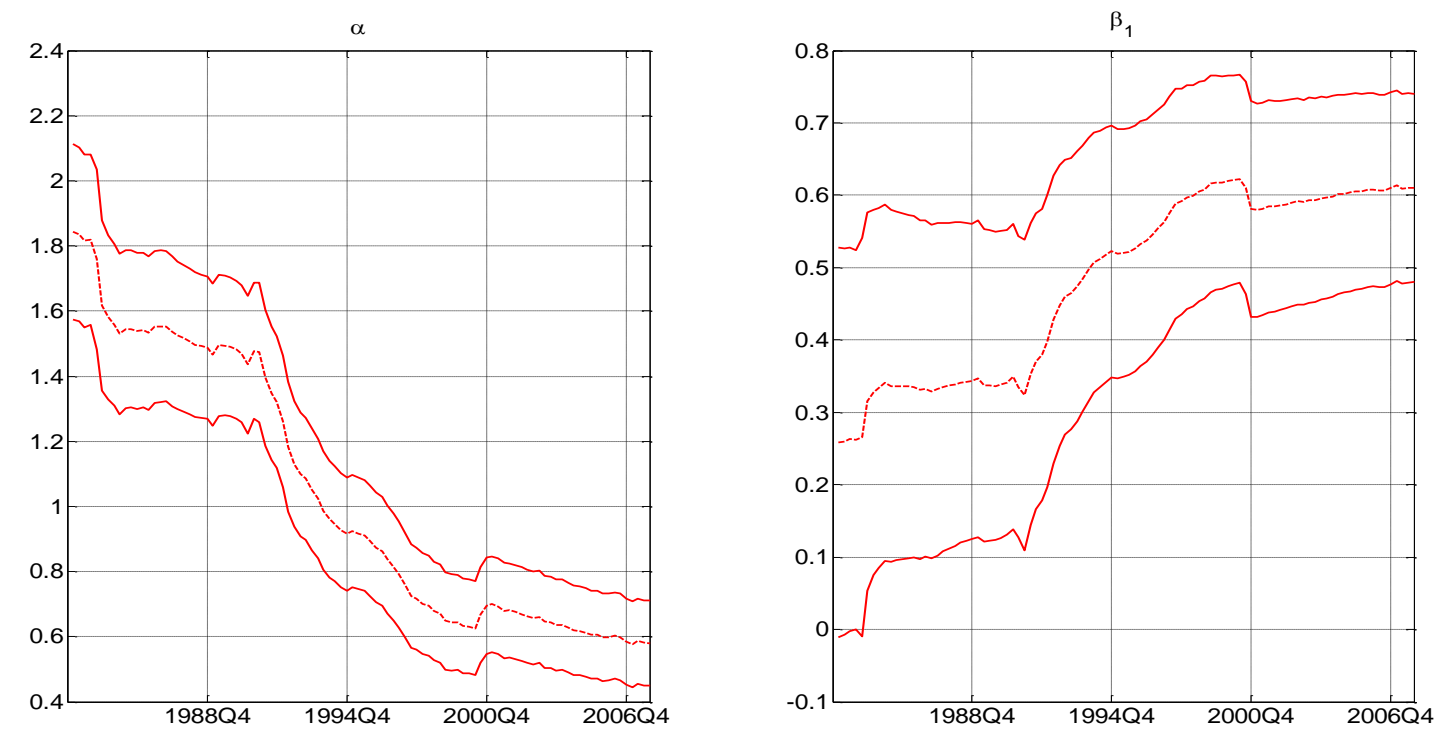

Note: Dashed line gives point estimate. Solid lines give plus/minus two standard errors. Sample is 1970Q1-1983Q1/2007Q4.

14 The recursive coefficient estimates are generated by estimating the models on an expanding sample (adding one observation at a time) and recording point estimates and standard errors each time. The first sample is 1970Q1 to 1983Q1 and the last sample is 1970Q1 to 2007Q4. 100 recursive estimates are hence generated for each model. 
Figure 4. Recursively estimated coefficients using OLS for AR(1) model for the Australian unemployment rate.
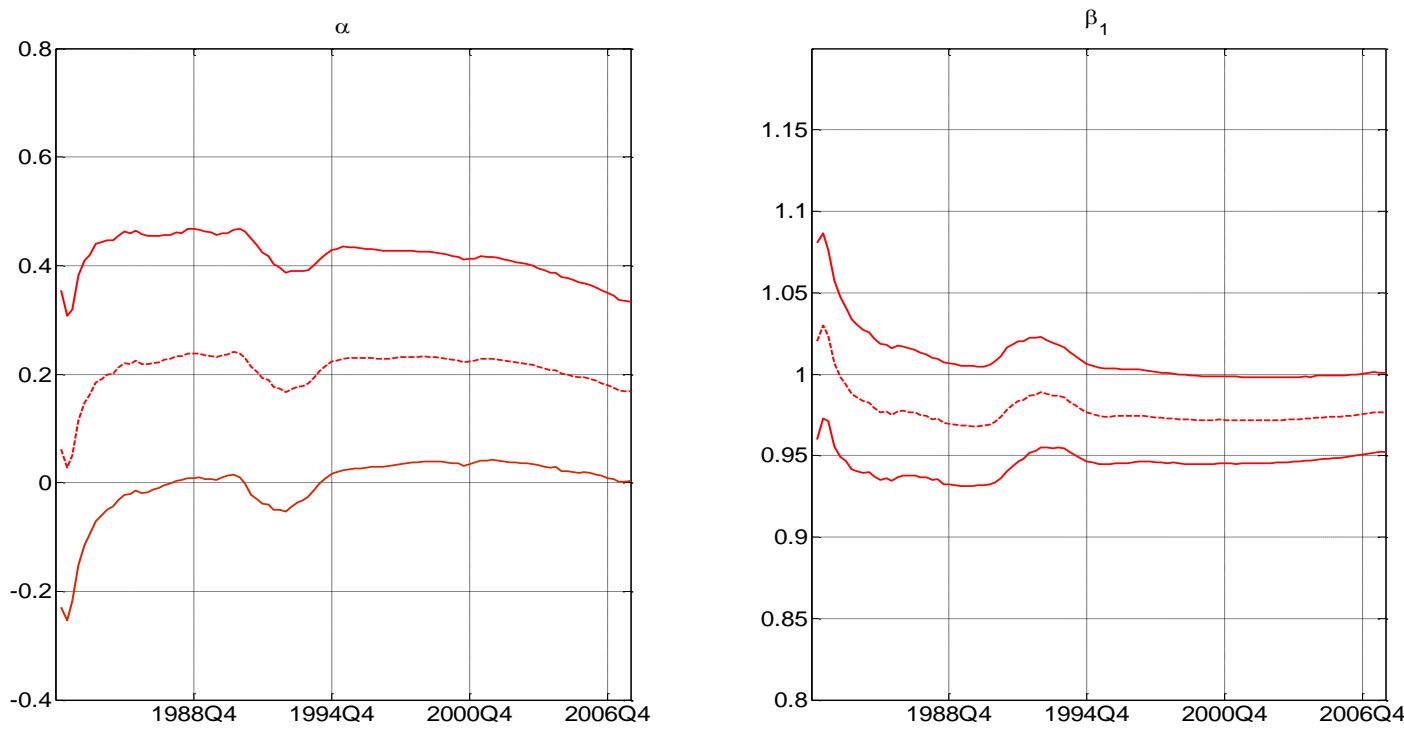

Note: Dashed line gives point estimate. Solid lines give plus/minus two standard errors. Sample is 1970Q1-1983Q1/2007Q4.

But while stability of the data-generating process might have some relevance in explaining our results, it is only part of the explanation. For Australia and Sweden, it appears that the main driver of our results is the fact that the CGLS estimator has a tendency to generate estimates of the AR coefficients that imply an explosive process, that is, the sum of the AR coefficients is larger than unity. This can be seen in Figures 5 and 6 which show the sum of the estimated AR coefficients for the AR(1) and AR(4) models for Australian and Swedish unemployment rate respectively. The left panel shows the sum of estimated coefficients when CGLS with a gain of $\kappa=0.10$ has been used and the right panel shows the corresponding sum when OLS has been used. ${ }^{15}$

${ }^{15}$ Figures A1 and A2 in the appendix show the corresponding graphs for the United Kindom and the United States. 
Figure 5. Estimated autoregressive coefficient from AR(1) models for the Australian unemployment rate.
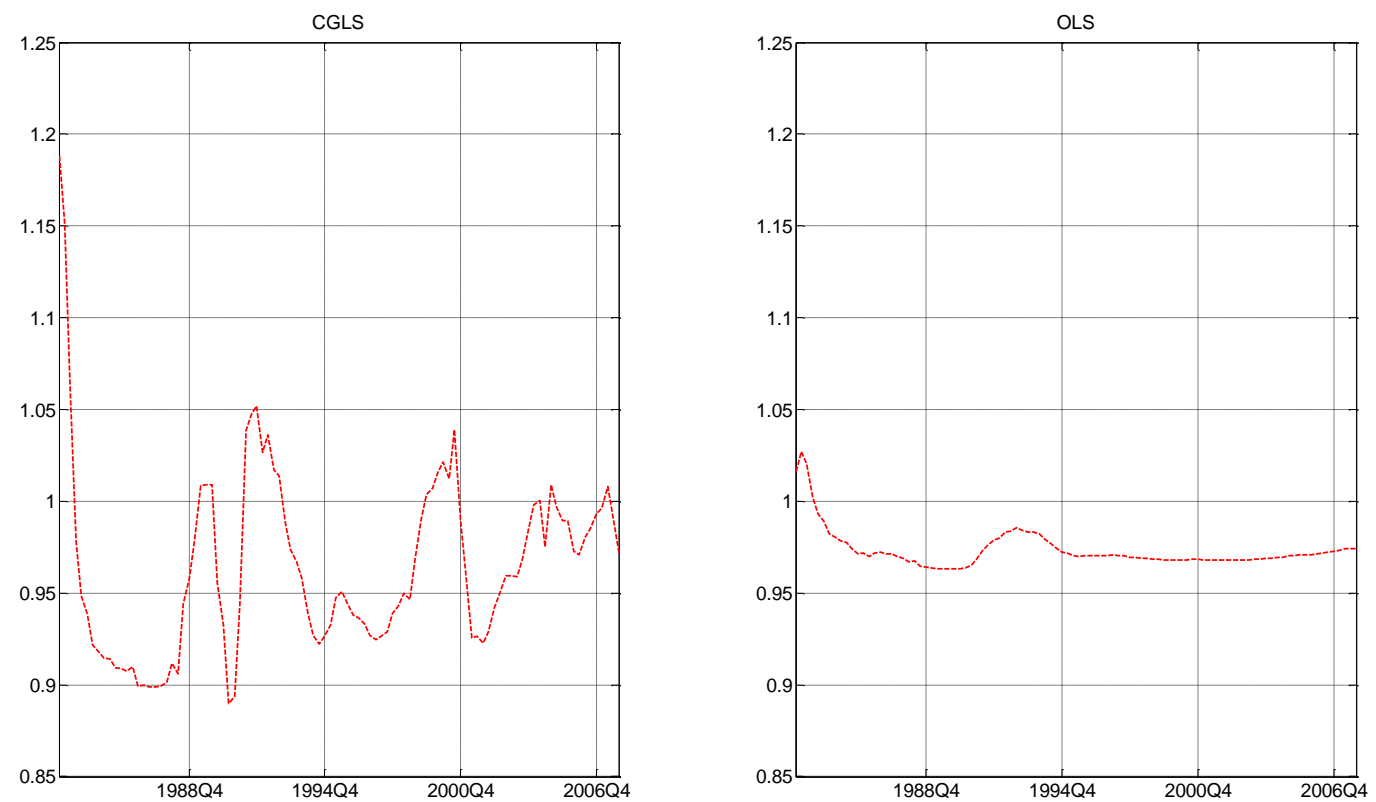

Note: CGLS gives estimates of autoregressive coefficient from model estimated with CGLS using a gain of 0.10 ; estimation is initialised at 1971Q2. OLS gives recursively estimated autoregressive coefficient from model estimated with OLS; sample is 1970Q1-1983Q1/2007Q4.

Figure 5 clearly shows how the CGLS estimator in many cases generates dynamics that imply an explosive process. This can be contrasted with the OLS estimator where this kind of dynamics is found only in the beginning of the evaluation period. For the Swedish data, Figure 6 shows that the number of occasions where CGLS generates explosive dynamics is fewer than in the Australian case. The problem is nevertheless present and still relevant in explaining our findings. It can be noted that CGLS generates explosive dynamics more often than OLS and that in the cases when both methods generate explosive dynamics, the sum of the AR coefficients is a fair bit larger for CGLS than for OLS; for forecasts at long horizons, this larger sum makes a substantial difference. ${ }^{16}$

16 While the estimated sum of the AR coefficients is considered the main problem, it should be noted that the estimate of the intercept of course also matters for the forecasts. It can alleviate or exacerbate the problem. 
Figure 6. Sum of estimated autoregressive coefficients from AR(4) models for the Swedish unemployment rate.
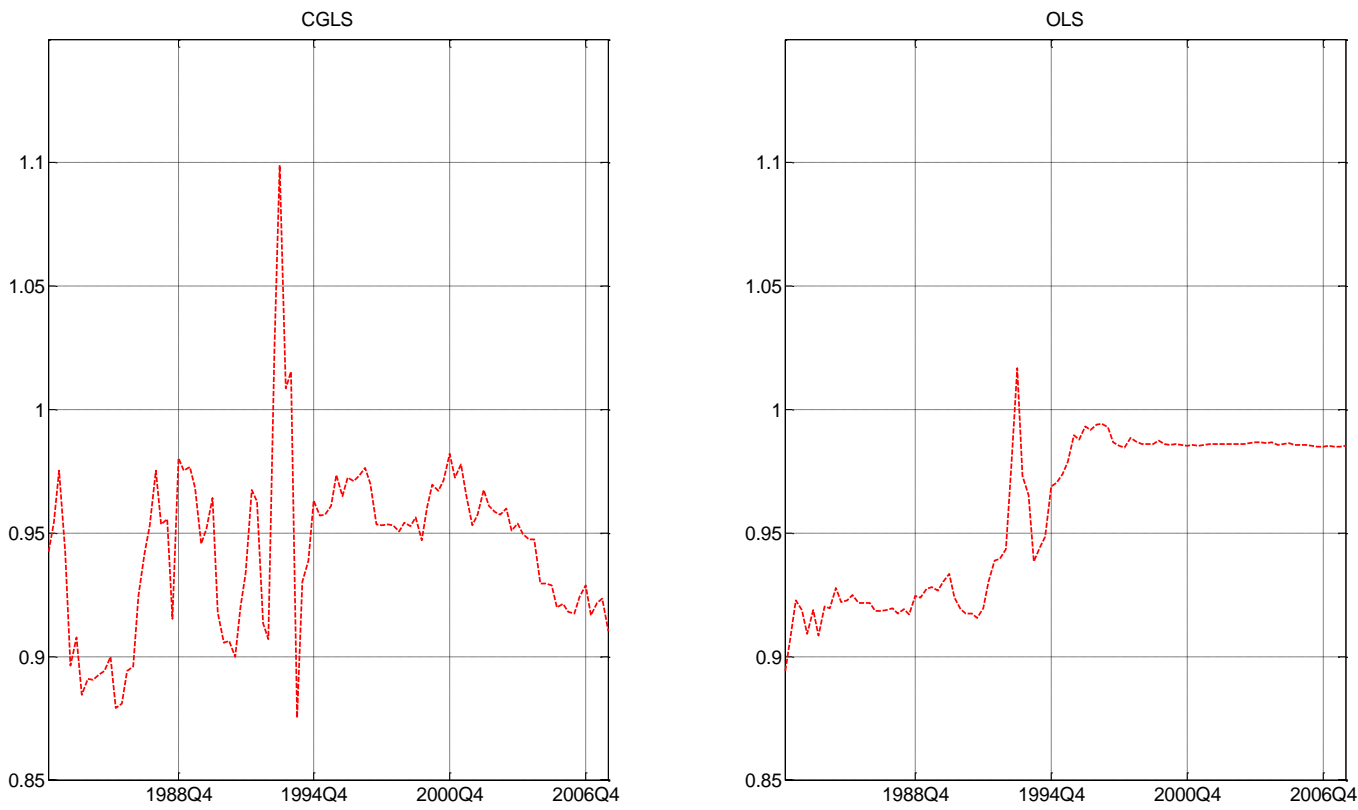

Note: CGLS gives the sum of estimated of autoregressive coefficients from model estimated with CGLSusing a gain of 0.10 estimation is initialised at 197102 . OLS gives the sum of recursively estimated autoregressive coefficients from model estimated with OLS; sample is 1970Q1-1983Q1/2007Q4.

The problems associated with forecasting with an explosive process are illustrated in Figure 7. The figure shows three forecasts - using data up to and including 1993Q2 - from AR(4) models for Swedish unemployment; these forecasts are based on models estimated with i) OLS, ii) CGLS with a gain of 0.03 and iii) CGLS with a gain of 0.10. In this case, all three models have explosive dynamics and generate forecasts that diverge. The problem is substantial for all three models. The model estimated with OLS does not perform as badly as the models estimated with CGLS but still generates a forecast for the unemployment rate eight quarters ahead which is more than 30 percent; needless to say, this would have been perceived as unreasonable by any economist in real time. 
Figure 7. Forecasts from AR(4) models for Swedish unemployment rate made using data including $1993 Q 2$.

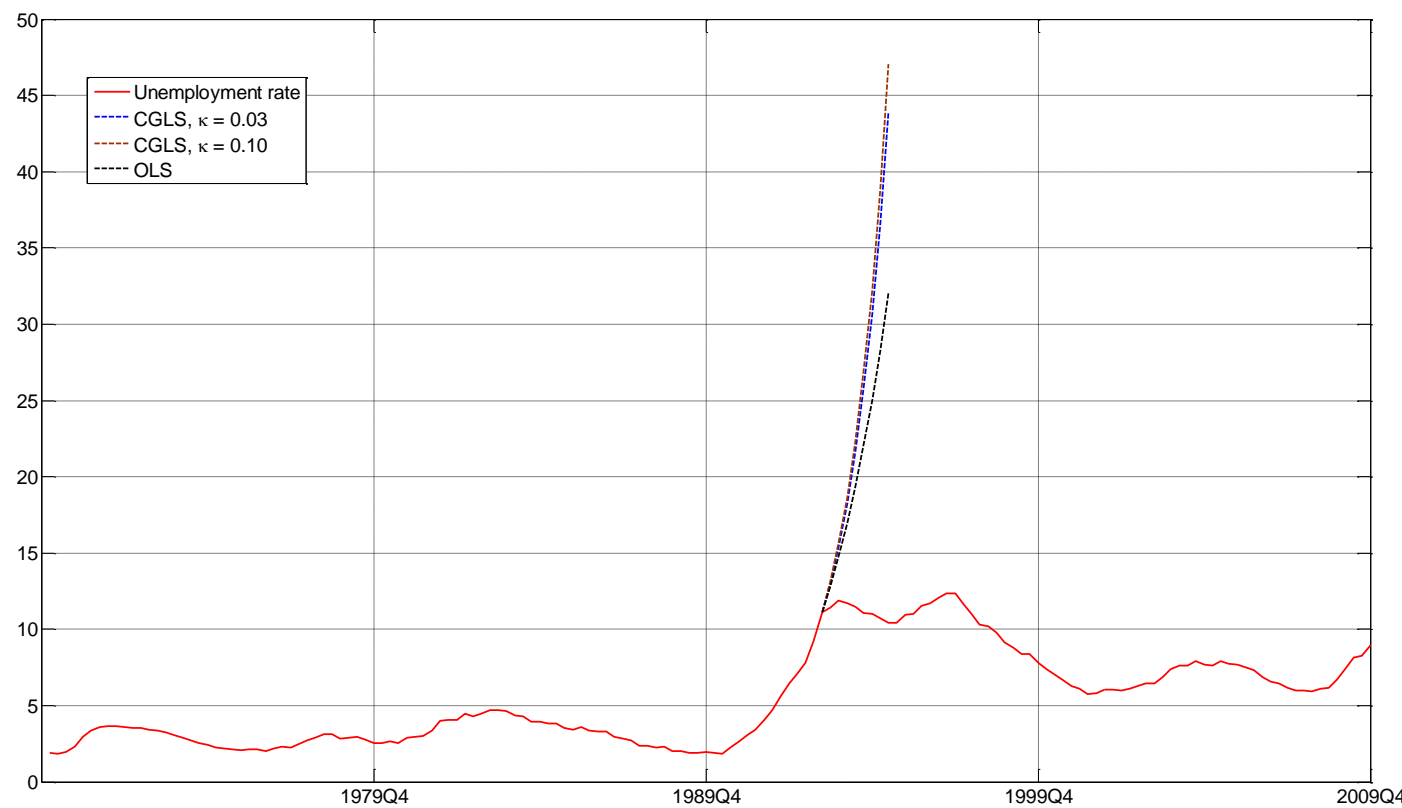

Note: CGLS estimation is initialised at 1971Q2. OLS sample is 1970Q1-1993Q2.

But while all models suffer from this problem, it is most severe for CGLS with a gain of 0.10 . The extent of the problem can be seen by noting that the squared forecast error at the eight-quarter horizon is 1339. This single observation contributes in a spectacular way to the RMSFE; in fact, roughly half of the sum of the squared forecast errors in equation (5) for the eight-quarter horizon stems from this observation. By comparison, the corresponding squared forecast error for the model estimated with OLS is 466 . While this is also a very large number, it is roughly 873 units smaller than that from CGLS with a gain of 0.10 . Needless to say, this makes a substantial difference for the RMSFE and helps explain why CGLS performs so badly for Sweden. ${ }^{17}$ From a more general perspective, it shows that a forecaster relying on CGLS to forecast highly persistent time series needs to pay extra attention to the forecasts being generated by the model.

\section{Conclusions}

This paper has added to the empirical literature on CGLS as a macroeconomic forecasting tool by investigating the out-of-sample forecast performance of AR models estimated with CGLS and OLS when forecasting the unemployment rate. Using data from Australia, Sweden, the United Kingdom and the United States, we find that CGLS does not appear particularly useful in terms of improving forecast precision relative to OLS. The failure of CGLS is particularly evident at longer forecast

17 That explosive dynamics constitutes a problem is also confirmed by the fact that CGLS performs approximately as well as OLS for the United Kingdom. As can be seen in Figure A1, the AR(4) model estimated with CGLS using a gain of 0.10 is not associated with explosive dynamics at any point in time. 
horizons. At horizons of six to eight quarters, OLS is always associated with higher forecast precision than CGLS, regardless of model size or gain employed for Australia, Sweden and the United States.

The fact that OLS tends to outperform CGLS is consistent with the time-series properties of the unemployment rate in the studied countries being stable; if the data-generating process does not change in a quantitatively meaningful way over time, we would expect the model which assumes parameter stability to work better from a forecasting perspective. However, for both Australia and Sweden, it appears that the main cause for the failure of CGLS is the fact that it has an increased tendency to generate estimates of the AR coefficients that imply an explosive process. With an explosive process, forecasts diverge and are in some cases associated with extremely large forecast errors. A forecaster can of course use good judgement and say that a given model forecast is unreasonable, thereby reducing the extent of this problem in practice. This does require both monitoring and a forecaster with good judgement though. We accordingly conclude that while CGLS in previous studies has been shown to have the potential to be a valuable contribution to the toolkit employed by forecasters, it is by no means a recipe for guaranteed success in macroeconomic forecasting. 


\section{References}

Akaike, H. (1974), “A New Look at the Statistical Model Identification”, IEEE Transactions on Automatic Control 19, 716-723.

Antipin, J.-E., Boumedienne, F. J. and Österholm, P. (2012), "Forecasting Inflation Using Constant Gain Least Squares", Working Paper 126, National Institute of Economic Research.

Apel, M. and Jansson, P. (1999), "A Theory-Consistent System Approach for Estimating Potential Output and the NAIRU”, Economics Letters 64, 271-275.

Armstrong, J. S. (2007), "Significance Tests Harm Progress in Forecasting", International Journal of Forecasting 23, 321-327.

Beechey, M. and Österholm, P. (2010), "Forecasting Inflation in an Inflation Targeting Regime: A Role for Informative Steady-State Priors", International Journal of Forecasting 26, 248-264.

Branch, W. A. and Evans, G. H. (2006), "A Simple Recursive Forecasting Model”, Economics Letters 91, 158-166.

Brown, L. and Moshiri, S. (2004), "Unemployment Variation over the Business Cycles: A Comparison of Forecasting Models", Journal of Forecasting 23, 497-511.

Camarero, M. and Tamarit, C. (2004), "Hysteresis vs. Natural Rate of Unemployment: New Evidence for OECD Countries", Economics Letters 84, 413-417.

Cogley, T. and Sargent, T. J. (2001), "Evolving Post-World War II U.S. Inflation Dynamics", NBER Macroeconomics Annual 16, 331-373.

Dale, S., Orphanides, A. and Österholm, P. (2011), "Imperfect Central Bank Communication: Information versus Distraction", International Journal of Central Banking 7, 3-39.

Debelle, G. and Vickery, J. (1998), "Is the Phillips Curve a Curve? Some Evidence and Implications for Australia”, Economic Record 74, 384-98.

Deschamps, P. J. (2008), "Comparing Smooth Transition and Markov Switching Autoregressive Models of US Unemployment", Journal of Applied Econometrics 23, 435-462.

Du Caju, P., Gautier, E., Momferatou, D. and Ward-Warmedinger, M. (2008), "Institutional Features of Wage Bargaining in 23 European Countries, the US and Japan," Working Paper 974, European Central Bank.

Dueker, M., Owyang, M. T. and Sola, M. (2010), “A Time-Varying Threshold STAR Model of Unemployment and the Natural Rate”, Working Paper 2010-029A, Federal Reserve Bank of St. Louis.

Evans, G. W. and Honkapohja, S. (2001), Learning and Expectations in Macroeconomics, Princeton University Press, Princeton. 
Franses, P. H., Paap, R. and Vroomen, B. (2004), "Forecasting Unemployment Using an Autoregression with Censored Latent Effects Parameters", International Journal of Forecasting 20, 255-271.

Funke, M. (1992), “Time-Series Forecasting of the German Unemployment Rate", Journal of Forecasting 11, 111-125.

Gaspar, V., Smets, F. and Vestin, D. (2006), “Adaptive Learning, Persistence and Optimal Monetary Policy”, Journal of the European Economic Association 4, 376-685.

Golan A. and Perloff, J. M. (2004) "Superior Forecasts of the US Unemployment Rate Using a Nonparametric Method", Review of Economics and Statistics 86, 433-438.

Gordon, R. J. (1997), “The Time-Varying NAIRU and Its Implications for Economic Policy”, Journal of Economic Perspectives 11, 11-32.

Gustavsson, M. and Österholm, P. (2007), "Does Unemployment Hysteresis Equal Employment Hysteresis?”, Economic Record 83, 159-173.

Hannan, E. J. and Quinn, B. G. (1979), "The Determination of the Order of an Autoregression", Journal of the Royal Statistical Society (Series B), 41, 190-195.

Hendry, D. F. (1995), Dynamic Econometrics. Oxford University Press, Oxford.

Jaeger, A. and Parkinson, M. (1994), "Some Evidence on Hysteresis in Unemployment Rates", European Economic Review 38, 329-342.

Larsson, L. (2003), "Evaluating Swedish Youth Labour Market Programs", Journal of Human Resources $38,891-927$.

Lim, G. C., Dixon, R. and Tsiaplias, S. (2009), "Phillips Curve and the Equilibrium Unemployment Rate", Economic Record 85, 371-382.

Litterman, R. B. (1986), "Forecasting with Bayesian Vector Autoregressions - Five Years of Experience", Joumal of Business and Economic Statistics 5, 25-38.

León-Ledesma, M. A. (2002), "Unemployment Hysteresis in the US States and the EU: A Panel Approach”, Bulletin of Economic Research 54, 95-105.

Lütkephol, H. (2007), “General-to-Specific or Specific-to-General Modelling? An Opinion on Current Econometric Terminology", Journal of Econometrics 136, 319-324.

Milas, C. and Rothman, P. (2008), "Out-of-Sample Forecasting of Unemployment Rates with Pooled STVECM Forecasts”, International Journal of Forecasting 24, 101-121.

Montgomery, A. L., Zarnowitz, V., Tsay, R. S. and Tiao, G. C. (1998), "Forecasting the U.S. Unemployment Rate", Journal of the American Statistical Association 93, 478-493.

Mortensen, D. T. (1977), "Unemployment Insurance and Job Search Decisions", Industrial and Labor Relations Review 30, 505-517. 
Orphanides, A. and Williams, J. C. (2004), "Imperfect Knowledge, Inflation Expectations and Monetary Policy", In: Bernanke, B. and Woodford, M. (eds), The Inflation Targeting Debate, University of Chicago Press, Chicago.

Papell, D. H., Murray, C. J. and Ghiblawi, H. (2000), “The Structure of Unemployment”, Review of Economics and Statistics 82, 309-315.

Pesaran, M. H., Schuermann, T. and Smith, L. V. (2009), "Forecasting Economic and Financial Variables with Global VARs", International Journal of Forecasting 25, 642-675.

Rothman, P. (1998), "Forecasting Asymmetric Unemployment Rates", Review of Economics and Statistics $80,164-168$.

Sargent, T. J. (1999), The Conquest of American Inflation, Princeton University Press, Princeton.

Schwarz, G. (1978), "Estimating the Dimension of a Model”, Annals of Statistics 6, 461-464.

Skalin, J. and Teräsvirta, T. (2002), "Modeling Asymmetries and Moving Equilibria in Unemployment Rates", Macroeconomic Dynamics 6, 202-241.

Summers, P. M. (2004), "Bayesian Evidence on the Structure of Unemployment", Economics Letters 83, 299-306.

Uusitalo, R. (2005). "Do Centralized Bargains Lead to Wage Moderation? Time-Series Evidence from Finland", In: Piekkola, H. and Snellman, K (eds), Collective Bargaining and Wage Formation. Performance and Challenges, Physica-Verlag, Heidelberg.

Webster, E. and Harding, G. (2001) "Outsourcing Public Employment Services: The Australian Experience", Australian Economic Review 34, 231-242. 


\section{Appendix}

Table A1. RMSFEs at different forecasting horizons for model estimated by CGLS and OLS Australia.

\begin{tabular}{|c|c|c|c|c|c|c|c|c|c|}
\hline & Gain & 0.01 & 0.02 & 0.03 & 0.04 & 0.05 & 0.075 & 0.10 & OLS \\
\hline \multirow[t]{9}{*}{1 lag } & Horizon & & & & & & & & \\
\hline & 1 & 0.305 & 0.302 & 0.300 & 0.299 & 0.299 & 0.302 & 0.305 & 0.304 \\
\hline & 2 & 0.559 & 0.554 & 0.551 & 0.553 & 0.557 & 0.576 & 0.600 & 0.548 \\
\hline & 3 & 0.818 & 0.812 & 0.810 & 0.815 & 0.827 & 0.876 & 0.939 & 0.788 \\
\hline & 4 & 1.066 & 1.058 & 1.058 & 1.068 & 1.089 & 1.175 & 1.289 & 1.012 \\
\hline & 5 & 1.304 & 1.295 & 1.298 & 1.315 & 1.346 & 1.480 & 1.663 & 1.220 \\
\hline & 6 & 1.534 & 1.525 & 1.531 & 1.557 & 1.601 & 1.793 & 2.071 & 1.413 \\
\hline & 7 & 1.747 & 1.738 & 1.749 & 1.784 & 1.843 & 2.103 & 2.499 & 1.585 \\
\hline & 8 & 1.954 & 1.945 & 1.963 & 2.008 & 2.085 & 2.425 & 2.970 & 1.747 \\
\hline \multirow[t]{9}{*}{2 lags } & Horizon & & & & & & & & \\
\hline & 1 & 0.246 & 0.241 & 0.239 & 0.237 & 0.236 & 0.237 & 0.240 & 0.242 \\
\hline & 2 & 0.453 & 0.438 & 0.430 & 0.425 & 0.424 & 0.432 & 0.451 & 0.436 \\
\hline & 3 & 0.696 & 0.676 & 0.665 & 0.660 & 0.661 & 0.686 & 0.731 & 0.660 \\
\hline & 4 & 0.933 & 0.907 & 0.893 & 0.887 & 0.891 & 0.935 & 1.010 & 0.873 \\
\hline & 5 & 1.159 & 1.128 & 1.113 & 1.107 & 1.115 & 1.185 & 1.298 & 1.067 \\
\hline & 6 & 1.379 & 1.344 & 1.327 & 1.322 & 1.334 & 1.431 & 1.592 & 1.248 \\
\hline & 7 & 1.578 & 1.538 & 1.519 & 1.516 & 1.531 & 1.656 & 1.869 & 1.402 \\
\hline & 8 & 1.776 & 1.731 & 1.712 & 1.710 & 1.728 & 1.881 & 2.152 & 1.548 \\
\hline \multirow[t]{9}{*}{3 lags } & Horizon & & & & & & & & \\
\hline & 1 & 0.229 & 0.226 & 0.225 & 0.224 & 0.225 & 0.230 & 0.242 & 0.223 \\
\hline & 2 & 0.414 & 0.409 & 0.406 & 0.406 & 0.408 & 0.426 & 0.460 & 0.393 \\
\hline & 3 & 0.646 & 0.639 & 0.638 & 0.640 & 0.648 & 0.696 & 0.778 & 0.603 \\
\hline & 4 & 0.870 & 0.861 & 0.859 & 0.863 & 0.877 & 0.957 & 1.090 & 0.801 \\
\hline & 5 & 1.089 & 1.076 & 1.073 & 1.080 & 1.101 & 1.221 & 1.419 & 0.987 \\
\hline & 6 & 1.305 & 1.288 & 1.286 & 1.295 & 1.324 & 1.487 & 1.755 & 1.163 \\
\hline & 7 & 1.502 & 1.481 & 1.479 & 1.491 & 1.526 & 1.732 & 2.078 & 1.314 \\
\hline & 8 & 1.699 & 1.675 & 1.673 & 1.688 & 1.730 & 1.980 & 2.410 & 1.459 \\
\hline \multirow[t]{9}{*}{4 lags } & Horizon & & & & & & & & \\
\hline & 1 & 0.233 & 0.231 & 0.230 & 0.231 & 0.232 & 0.241 & 0.257 & 0.225 \\
\hline & 2 & 0.428 & 0.424 & 0.424 & 0.426 & 0.431 & 0.457 & 0.499 & 0.402 \\
\hline & 3 & 0.670 & 0.669 & 0.671 & 0.677 & 0.689 & 0.745 & 0.835 & 0.618 \\
\hline & 4 & 0.903 & 0.901 & 0.906 & 0.916 & 0.936 & 1.030 & 1.182 & 0.821 \\
\hline & 5 & 1.130 & 1.128 & 1.135 & 1.150 & 1.180 & 1.323 & 1.551 & 1.010 \\
\hline & 6 & 1.354 & 1.351 & 1.360 & 1.382 & 1.424 & 1.628 & 1.954 & 1.188 \\
\hline & 7 & 1.557 & 1.552 & 1.565 & 1.593 & 1.648 & 1.921 & 2.363 & 1.341 \\
\hline & 8 & 1.760 & 1.753 & 1.769 & 1.805 & 1.875 & 2.227 & 2.816 & 1.487 \\
\hline
\end{tabular}

Note: Forecasting horizon is given in quarters. 
Table A2. RMSFEs at different forecasting horizons for model estimated by CGLS and OLS Sweden.

\begin{tabular}{|c|c|c|c|c|c|c|c|c|c|}
\hline & Gain & 0.01 & 0.02 & 0.03 & 0.04 & 0.05 & 0.075 & 0.10 & OLS \\
\hline \multirow[t]{9}{*}{$1 \mathrm{lag}$} & Horizon & & & & & & & & \\
\hline & 1 & 0.428 & 0.426 & 0.423 & 0.418 & 0.414 & 0.400 & 0.387 & 0.431 \\
\hline & 2 & 0.852 & 0.856 & 0.853 & 0.847 & 0.840 & 0.815 & 0.789 & 0.851 \\
\hline & 3 & 1.326 & 1.346 & 1.352 & 1.349 & 1.341 & 1.309 & 1.271 & 1.312 \\
\hline & 4 & 1.849 & 1.902 & 1.928 & 1.936 & 1.932 & 1.897 & 1.850 & 1.811 \\
\hline & 5 & 2.427 & 2.533 & 2.594 & 2.624 & 2.634 & 2.612 & 2.561 & 2.350 \\
\hline & 6 & 3.048 & 3.230 & 3.344 & 3.410 & 3.444 & 3.454 & 3.413 & 2.916 \\
\hline & 7 & 3.722 & 4.007 & 4.195 & 4.314 & 4.385 & 4.452 & 4.442 & 3.518 \\
\hline & 8 & 4.453 & 4.876 & 5.165 & 5.354 & 5.477 & 5.625 & 5.670 & 4.158 \\
\hline \multirow[t]{9}{*}{2 lags } & Horizon & & & & & & & & \\
\hline & 1 & 0.352 & 0.335 & 0.329 & 0.327 & 0.327 & 0.330 & 0.337 & 0.318 \\
\hline & 2 & 0.739 & 0.701 & 0.688 & 0.687 & 0.691 & 0.706 & 0.724 & 0.638 \\
\hline & 3 & 1.211 & 1.160 & 1.145 & 1.149 & 1.159 & 1.190 & 1.219 & 1.026 \\
\hline & 4 & 1.762 & 1.709 & 1.695 & 1.706 & 1.726 & 1.775 & 1.813 & 1.462 \\
\hline & 5 & 2.406 & 2.367 & 2.364 & 2.390 & 2.425 & 2.499 & 2.545 & 1.951 \\
\hline & 6 & 3.123 & 3.114 & 3.128 & 3.176 & 3.234 & 3.348 & 3.411 & 2.452 \\
\hline & 7 & 3.936 & 3.979 & 4.020 & 4.100 & 4.190 & 4.362 & 4.452 & 2.980 \\
\hline & 8 & 4.858 & 4.976 & 5.058 & 5.179 & 5.314 & 5.567 & 5.697 & 3.530 \\
\hline \multirow[t]{9}{*}{3 lags } & Horizon & & & & & & & & \\
\hline & 1 & 0.345 & 0.333 & 0.329 & 0.328 & 0.329 & 0.340 & 0.359 & 0.314 \\
\hline & 2 & 0.698 & 0.679 & 0.674 & 0.678 & 0.687 & 0.725 & 0.786 & 0.622 \\
\hline & 3 & 1.148 & 1.123 & 1.119 & 1.130 & 1.148 & 1.217 & 1.305 & 0.999 \\
\hline & 4 & 1.684 & 1.659 & 1.660 & 1.679 & 1.708 & 1.803 & 1.898 & 1.434 \\
\hline & 5 & 2.321 & 2.310 & 2.323 & 2.356 & 2.401 & 2.525 & 2.627 & 1.935 \\
\hline & 6 & 3.039 & 3.054 & 3.085 & 3.140 & 3.205 & 3.369 & 3.491 & 2.459 \\
\hline & 7 & 3.861 & 3.919 & 3.980 & 4.065 & 4.159 & 4.373 & 4.517 & 3.021 \\
\hline & 8 & 4.792 & 4.911 & 5.012 & 5.138 & 5.271 & 5.550 & 5.710 & 3.605 \\
\hline \multirow[t]{9}{*}{4 lags } & Horizon & & & & & & & & \\
\hline & 1 & 0.349 & 0.351 & 0.357 & 0.368 & 0.381 & 0.418 & 0.456 & 0.326 \\
\hline & 2 & 0.684 & 0.695 & 0.714 & 0.738 & 0.764 & 0.833 & 0.895 & 0.641 \\
\hline & 3 & 1.072 & 1.083 & 1.111 & 1.142 & 1.171 & 1.233 & 1.278 & 1.014 \\
\hline & 4 & 1.563 & 1.581 & 1.620 & 1.663 & 1.699 & 1.759 & 1.778 & 1.452 \\
\hline & 5 & 2.138 & 2.185 & 2.258 & 2.334 & 2.403 & 2.546 & 2.653 & 1.962 \\
\hline & 6 & 2.767 & 2.842 & 2.949 & 3.056 & 3.151 & 3.342 & 3.475 & 2.501 \\
\hline & 7 & 3.479 & 3.601 & 3.752 & 3.893 & 4.005 & 4.168 & 4.207 & 3.081 \\
\hline & 8 & 4.251 & 4.436 & 4.652 & 4.850 & 5.011 & 5.245 & 5.277 & 3.665 \\
\hline
\end{tabular}

Note: Forecasting horizon is given in quarters. 
Table A3. RMSFEs at different forecasting horizons for model estimated by CGLS and OLS United Kingdom.

\begin{tabular}{|c|c|c|c|c|c|c|c|c|c|}
\hline & Gain & 0.01 & 0.02 & 0.03 & 0.04 & 0.05 & 0.075 & 0.10 & OLS \\
\hline \multirow[t]{9}{*}{$1 \mathrm{lag}$} & Horizon & & & & & & & & \\
\hline & 1 & 0.263 & 0.257 & 0.252 & 0.247 & 0.243 & 0.233 & 0.224 & 0.269 \\
\hline & 2 & 0.508 & 0.495 & 0.483 & 0.474 & 0.466 & 0.450 & 0.435 & 0.517 \\
\hline & 3 & 0.757 & 0.737 & 0.719 & 0.706 & 0.695 & 0.676 & 0.660 & 0.766 \\
\hline & 4 & 1.007 & 0.978 & 0.955 & 0.937 & 0.924 & 0.907 & 0.895 & 1.012 \\
\hline & 5 & 1.265 & 1.227 & 1.196 & 1.173 & 1.159 & 1.147 & 1.145 & 1.261 \\
\hline & 6 & 1.527 & 1.479 & 1.441 & 1.413 & 1.396 & 1.391 & 1.406 & 1.511 \\
\hline & 7 & 1.788 & 1.729 & 1.683 & 1.648 & 1.629 & 1.632 & 1.670 & 1.758 \\
\hline & 8 & 2.048 & 1.978 & 1.921 & 1.880 & 1.857 & 1.869 & 1.935 & 2.001 \\
\hline \multirow[t]{9}{*}{2 lags } & Horizon & & & & & & & & \\
\hline & 1 & 0.161 & 0.155 & 0.153 & 0.152 & 0.150 & 0.147 & 0.146 & 0.157 \\
\hline & 2 & 0.309 & 0.287 & 0.282 & 0.279 & 0.278 & 0.279 & 0.283 & 0.284 \\
\hline & 3 & 0.502 & 0.458 & 0.447 & 0.442 & 0.440 & 0.441 & 0.452 & 0.446 \\
\hline & 4 & 0.713 & 0.643 & 0.625 & 0.618 & 0.615 & 0.621 & 0.643 & 0.616 \\
\hline & 5 & 0.949 & 0.852 & 0.824 & 0.814 & 0.809 & 0.818 & 0.854 & 0.801 \\
\hline & 6 & 1.206 & 1.081 & 1.042 & 1.025 & 1.016 & 1.023 & 1.073 & 1.001 \\
\hline & 7 & 1.463 & 1.310 & 1.260 & 1.236 & 1.222 & 1.226 & 1.292 & 1.192 \\
\hline & 8 & 1.730 & 1.554 & 1.493 & 1.464 & 1.444 & 1.446 & 1.530 & 1.391 \\
\hline \multirow[t]{9}{*}{3 lags } & Horizon & & & & & & & & \\
\hline & 1 & 0.150 & 0.147 & 0.145 & 0.143 & 0.143 & 0.142 & 0.144 & 0.157 \\
\hline & 2 & 0.286 & 0.282 & 0.282 & 0.283 & 0.285 & 0.290 & 0.298 & 0.291 \\
\hline & 3 & 0.462 & 0.451 & 0.450 & 0.452 & 0.454 & 0.466 & 0.486 & 0.456 \\
\hline & 4 & 0.655 & 0.637 & 0.633 & 0.634 & 0.638 & 0.659 & 0.695 & 0.628 \\
\hline & 5 & 0.874 & 0.844 & 0.836 & 0.836 & 0.841 & 0.872 & 0.927 & 0.812 \\
\hline & 6 & 1.113 & 1.069 & 1.054 & 1.047 & 1.048 & 1.082 & 1.155 & 1.010 \\
\hline & 7 & 1.355 & 1.294 & 1.269 & 1.255 & 1.251 & 1.283 & 1.373 & 1.194 \\
\hline & 8 & 1.605 & 1.528 & 1.496 & 1.475 & 1.465 & 1.495 & 1.604 & 1.388 \\
\hline \multirow[t]{9}{*}{4 lags } & Horizon & & & & & & & & \\
\hline & 1 & 0.150 & 0.149 & 0.148 & 0.147 & 0.146 & 0.145 & 0.146 & 0.157 \\
\hline & 2 & 0.287 & 0.284 & 0.285 & 0.286 & 0.286 & 0.286 & 0.290 & 0.298 \\
\hline & 3 & 0.463 & 0.457 & 0.457 & 0.456 & 0.454 & 0.450 & 0.461 & 0.472 \\
\hline & 4 & 0.656 & 0.646 & 0.649 & 0.650 & 0.647 & 0.645 & 0.666 & 0.658 \\
\hline & 5 & 0.875 & 0.858 & 0.863 & 0.867 & 0.866 & 0.869 & 0.906 & 0.862 \\
\hline & 6 & 1.114 & 1.085 & 1.088 & 1.092 & 1.090 & 1.093 & 1.144 & 1.080 \\
\hline & 7 & 1.356 & 1.312 & 1.311 & 1.312 & 1.306 & 1.306 & 1.371 & 1.290 \\
\hline & 8 & 1.606 & 1.549 & 1.544 & 1.543 & 1.534 & 1.531 & 1.612 & 1.510 \\
\hline
\end{tabular}

Note: Forecasting horizon is given in quarters. 
Table A4. RMSFEs at different forecasting horizons for model estimated by CGLS and OLS United States.

\begin{tabular}{|c|c|c|c|c|c|c|c|c|c|}
\hline & Gain & 0.01 & 0.02 & 0.03 & 0.04 & 0.05 & 0.075 & 0.10 & OLS \\
\hline \multirow[t]{9}{*}{1 lag } & Horizon & & & & & & & & \\
\hline & 1 & 0.242 & 0.244 & 0.245 & 0.245 & 0.246 & 0.245 & 0.243 & 0.245 \\
\hline & 2 & 0.452 & 0.457 & 0.460 & 0.462 & 0.464 & 0.464 & 0.462 & 0.455 \\
\hline & 3 & 0.647 & 0.657 & 0.663 & 0.667 & 0.670 & 0.673 & 0.672 & 0.648 \\
\hline & 4 & 0.825 & 0.840 & 0.850 & 0.858 & 0.863 & 0.869 & 0.870 & 0.823 \\
\hline & 5 & 0.999 & 1.020 & 1.035 & 1.047 & 1.055 & 1.066 & 1.070 & 0.994 \\
\hline & 6 & 1.184 & 1.212 & 1.233 & 1.248 & 1.260 & 1.277 & 1.286 & 1.177 \\
\hline & 7 & 1.363 & 1.400 & 1.426 & 1.446 & 1.462 & 1.488 & 1.503 & 1.353 \\
\hline & 8 & 1.531 & 1.576 & 1.609 & 1.634 & 1.654 & 1.689 & 1.714 & 1.516 \\
\hline \multirow[t]{9}{*}{2 lags } & Horizon & & & & & & & & \\
\hline & 1 & 0.203 & 0.187 & 0.180 & 0.176 & 0.175 & 0.178 & 0.181 & 0.171 \\
\hline & 2 & 0.402 & 0.368 & 0.348 & 0.339 & 0.337 & 0.344 & 0.357 & 0.319 \\
\hline & 3 & 0.602 & 0.553 & 0.523 & 0.510 & 0.509 & 0.525 & 0.550 & 0.479 \\
\hline & 4 & 0.792 & 0.728 & 0.690 & 0.675 & 0.675 & 0.698 & 0.734 & 0.644 \\
\hline & 5 & 0.983 & 0.902 & 0.856 & 0.841 & 0.843 & 0.875 & 0.921 & 0.812 \\
\hline & 6 & 1.189 & 1.092 & 1.039 & 1.023 & 1.028 & 1.067 & 1.119 & 0.995 \\
\hline & 7 & 1.392 & 1.277 & 1.217 & 1.204 & 1.213 & 1.262 & 1.324 & 1.163 \\
\hline & 8 & 1.587 & 1.454 & 1.389 & 1.378 & 1.392 & 1.454 & 1.528 & 1.318 \\
\hline \multirow[t]{9}{*}{3 lags } & Horizon & & & & & & & & \\
\hline & 1 & 0.207 & 0.192 & 0.183 & 0.179 & 0.178 & 0.181 & 0.187 & 0.176 \\
\hline & 2 & 0.421 & 0.388 & 0.364 & 0.351 & 0.348 & 0.359 & 0.379 & 0.328 \\
\hline & 3 & 0.630 & 0.586 & 0.551 & 0.533 & 0.532 & 0.567 & 0.620 & 0.491 \\
\hline & 4 & 0.824 & 0.767 & 0.724 & 0.704 & 0.707 & 0.775 & 0.877 & 0.659 \\
\hline & 5 & 1.016 & 0.943 & 0.889 & 0.868 & 0.876 & 0.989 & 1.171 & 0.825 \\
\hline & 6 & 1.224 & 1.133 & 1.070 & 1.046 & 1.058 & 1.217 & 1.510 & 1.005 \\
\hline & 7 & 1.428 & 1.320 & 1.248 & 1.224 & 1.241 & 1.466 & 1.932 & 1.168 \\
\hline & 8 & 1.625 & 1.500 & 1.420 & 1.397 & 1.422 & 1.730 & 2.448 & 1.319 \\
\hline \multirow[t]{9}{*}{4 lags } & Horizon & & & & & & & & \\
\hline & 1 & 0.202 & 0.191 & 0.184 & 0.181 & 0.181 & 0.188 & 0.197 & 0.178 \\
\hline & 2 & 0.414 & 0.387 & 0.366 & 0.356 & 0.354 & 0.370 & 0.393 & 0.330 \\
\hline & 3 & 0.650 & 0.607 & 0.570 & 0.549 & 0.545 & 0.576 & 0.626 & 0.492 \\
\hline & 4 & 0.861 & 0.810 & 0.760 & 0.731 & 0.726 & 0.786 & 0.883 & 0.656 \\
\hline & 5 & 1.057 & 0.997 & 0.937 & 0.903 & 0.900 & 1.001 & 1.165 & 0.822 \\
\hline & 6 & 1.252 & 1.183 & 1.117 & 1.083 & 1.085 & 1.238 & 1.503 & 1.002 \\
\hline & 7 & 1.443 & 1.363 & 1.293 & 1.261 & 1.272 & 1.504 & 1.927 & 1.166 \\
\hline & 8 & 1.629 & 1.538 & 1.463 & 1.434 & 1.455 & 1.789 & 2.446 & 1.319 \\
\hline
\end{tabular}

Note: Forecasting horizon is given in quarters 
Figure A1. Sum of estimated autoregressive coefficients from AR(4) models for the UK unemployment rate.
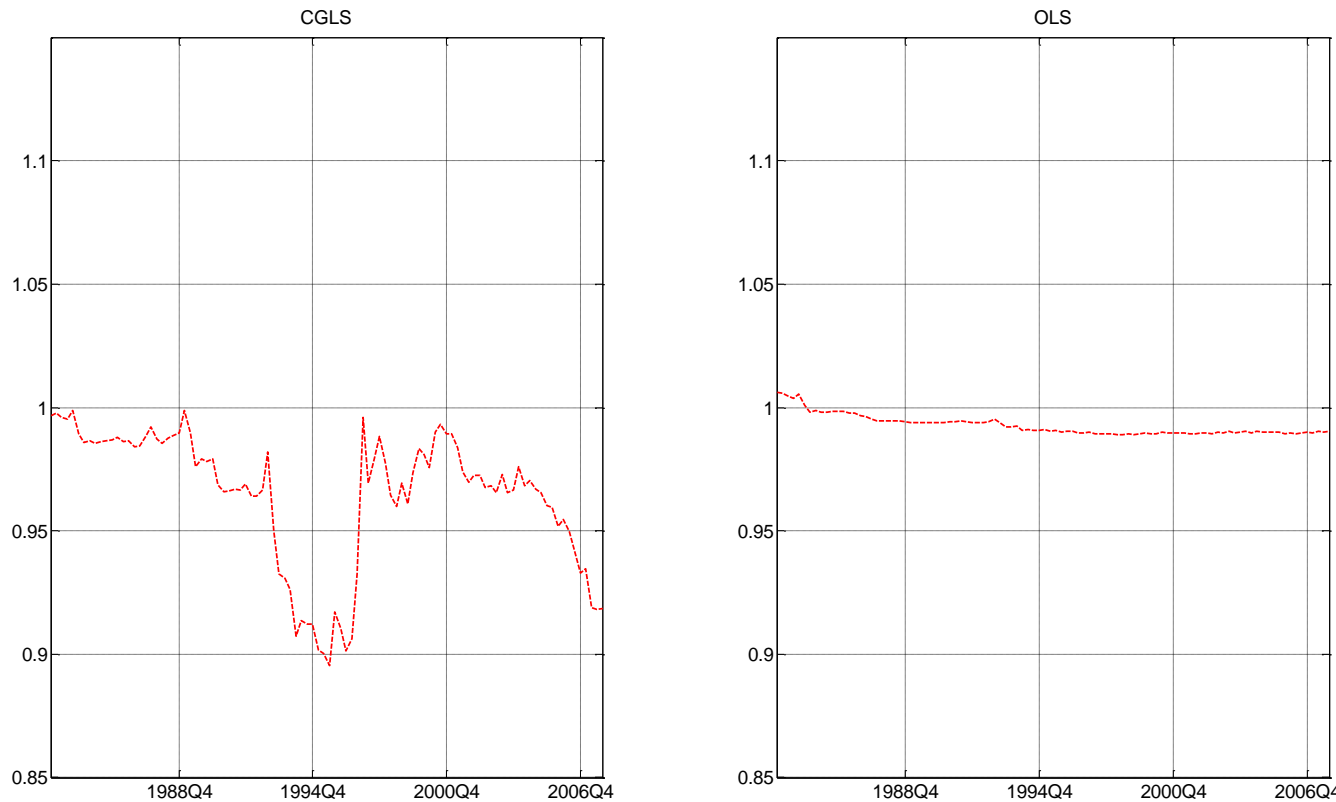

Note: CGLS gives the sum of estimated of autoregressive coefficients from model estimated with CGLS using a gain of 0.10 ; estimation is initialised at 1971Q2. OLS gives the sum of recursively estimated autoregressive coefficients from model estimated with OLS; sample is 1970Q1-1983Q1/2007Q4.

Figure A2. Sum of estimated autoregressive coefficients from AR(2) models for the US unemployment rate.
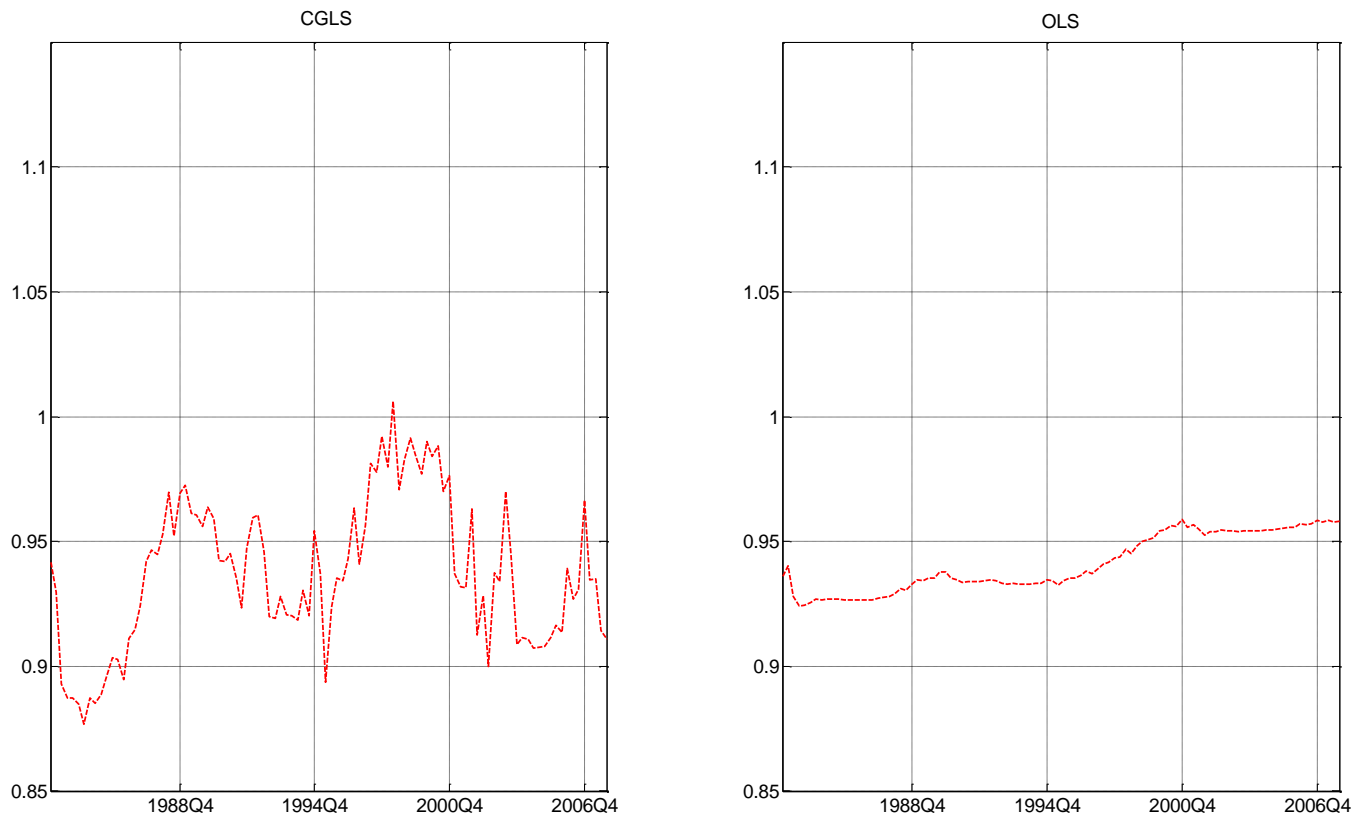

Note: CGLS gives the sum of estimated of autoregressive coefficients from model estimated with CGLS using a gain of 0.10; estimation is initialised at 197102. OLS gives the sum of recursively estimated autoregressive coefficients from model estimated with OLS; sample is 1970Q1-1983Q1/2007Q4. 


\section{Titles in the Working Paper Series}

\begin{tabular}{|c|c|c|c|}
\hline No & Author & Title & Year \\
\hline 1 & $\begin{array}{l}\text { Warne, Anders and } \\
\text { Anders Vredin }\end{array}$ & $\begin{array}{l}\text { Current Account and Business Cycles: Stylized Facts } \\
\text { for Sweden }\end{array}$ & 1989 \\
\hline 2 & Östblom, Göran & $\begin{array}{l}\text { Change in Technical Structure of the Swedish Econ- } \\
\text { omy }\end{array}$ & 1989 \\
\hline 3 & Söderling, Paul & $\begin{array}{l}\text { Mamtax. A Dynamic CGE Model for Tax Reform } \\
\text { Simulations }\end{array}$ & 1989 \\
\hline 4 & $\begin{array}{l}\text { Kanis, Alfred and } \\
\text { Aleksander Markowski }\end{array}$ & $\begin{array}{l}\text { The Supply Side of the Econometric Model of the } \\
\text { NIER }\end{array}$ & 1990 \\
\hline 5 & Berg, Lennart & The Financial Sector in the SNEPQ Model & 1991 \\
\hline 6 & $\begin{array}{l}\text { Ågren, Anders and Bo } \\
\text { Jonsson }\end{array}$ & $\begin{array}{l}\text { Consumer Attitudes, Buying Intentions and Con- } \\
\text { sumption Expenditures. An Analysis of the Swedish } \\
\text { Household Survey Data }\end{array}$ & 1991 \\
\hline 7 & $\begin{array}{l}\text { Berg, Lennart and } \\
\text { Reinhold Bergström }\end{array}$ & $\begin{array}{l}\text { A Quarterly Consumption Function for Sweden 1979- } \\
1989\end{array}$ & 1991 \\
\hline 8 & Öller, Lars-Erik & $\begin{array}{l}\text { Good Business Cycle Forecasts - A Must for Stabiliza- } \\
\text { tion Policies }\end{array}$ & 1992 \\
\hline 9 & $\begin{array}{l}\text { Jonsson, Bo and An- } \\
\text { ders Ågren }\end{array}$ & $\begin{array}{l}\text { Forecasting Car Expenditures Using Household Sur- } \\
\text { vey Data }\end{array}$ & 1992 \\
\hline 10 & $\begin{array}{l}\text { Löfgren, Karl-Gustaf, } \\
\text { Bo Ranneby and Sara } \\
\text { Sjöstedt }\end{array}$ & $\begin{array}{l}\text { Forecasting the Business Cycle Not Using Minimum } \\
\text { Autocorrelation Factors }\end{array}$ & 1992 \\
\hline 11 & Gerlach, Stefan & $\begin{array}{l}\text { Current Quarter Forecasts of Swedish GNP Using } \\
\text { Monthly Variables }\end{array}$ & 1992 \\
\hline 12 & Bergström, Reinhold & $\begin{array}{l}\text { The Relationship Between Manufacturing Production } \\
\text { and Different Business Survey Series in Sweden }\end{array}$ & 1992 \\
\hline 13 & $\begin{array}{l}\text { Edlund, Per-Olov and } \\
\text { Sune Karlsson }\end{array}$ & $\begin{array}{l}\text { Forecasting the Swedish Unemployment Rate: VAR } \\
\text { vs. Transfer Function Modelling }\end{array}$ & 1992 \\
\hline 14 & $\begin{array}{l}\text { Rahiala, Markku and } \\
\text { Timo Teräsvirta }\end{array}$ & $\begin{array}{l}\text { Business Survey Data in Forecasting the Output of } \\
\text { Swedish and Finnish Metal and Engineering Indus- } \\
\text { tries: A Kalman Filter Approach }\end{array}$ & 1992 \\
\hline 15 & $\begin{array}{l}\text { Christofferson, An- } \\
\text { ders, Roland Roberts } \\
\text { and Ulla Eriksson }\end{array}$ & $\begin{array}{l}\text { The Relationship Between Manufacturing and Various } \\
\text { BTS Series in Sweden Illuminated by Frequency and } \\
\text { Complex Demodulate Methods }\end{array}$ & 1992 \\
\hline 16 & Jonsson, Bo & $\begin{array}{l}\text { Sample Based Proportions as Values on an Independ- } \\
\text { ent Variable in a Regression Model }\end{array}$ & 1992 \\
\hline 17 & Öller, Lars-Erik & $\begin{array}{l}\text { Eliciting Turning Point Warnings from Business Sur- } \\
\text { veys }\end{array}$ & 1992 \\
\hline 18 & Forster, Margaret M & $\begin{array}{l}\text { Volatility, Trading Mechanisms and International } \\
\text { Cross-Listing }\end{array}$ & 1992 \\
\hline 19 & Jonsson, Bo & $\begin{array}{l}\text { Prediction with a Linear Regression Model and Errors } \\
\text { in a Regressor }\end{array}$ & 1992 \\
\hline
\end{tabular}




\begin{tabular}{|c|c|c|c|}
\hline 20 & $\begin{array}{l}\text { Gorton, Gary and } \\
\text { Richard Rosen }\end{array}$ & $\begin{array}{l}\text { Corporate Control, Portfolio Choice, and the Decline } \\
\text { of Banking }\end{array}$ & 1993 \\
\hline 21 & $\begin{array}{l}\text { Gustafsson, Claes- } \\
\text { Håkan and Åke Hol- } \\
\text { mén }\end{array}$ & $\begin{array}{l}\text { The Index of Industrial Production - A Formal De- } \\
\text { scription of the Process Behind it }\end{array}$ & 1993 \\
\hline 22 & Karlsson, Tohmas & $\begin{array}{l}\text { A General Equilibrium Analysis of the Swedish Tax } \\
\text { Reforms 1989-1991 }\end{array}$ & 1993 \\
\hline 23 & Jonsson, Bo & $\begin{array}{l}\text { Forecasting Car Expenditures Using Household Sur- } \\
\text { vey Data- A Comparison of Different Predictors }\end{array}$ & 1993 \\
\hline 24 & $\begin{array}{l}\text { Gennotte, Gerard and } \\
\text { Hayne Leland }\end{array}$ & Low Margins, Derivative Securitites and Volatility & 1993 \\
\hline 25 & $\begin{array}{l}\text { Boot, Arnoud W.A. } \\
\text { and Stuart I. Green- } \\
\text { baum }\end{array}$ & Discretion in the Regulation of U.S. Banking & 1993 \\
\hline 26 & $\begin{array}{l}\text { Spiegel, Matthew and } \\
\text { Deane J. Seppi }\end{array}$ & $\begin{array}{l}\text { Does Round-the-Clock Trading Result in Pareto Im- } \\
\text { provements? }\end{array}$ & 1993 \\
\hline 27 & Seppi, Deane J. & $\begin{array}{l}\text { How Important are Block Trades in the Price Discov- } \\
\text { ery Process? }\end{array}$ & 1993 \\
\hline 28 & Glosten, Lawrence R. & Equilibrium in an Electronic Open Limit Order Book & 1993 \\
\hline 29 & $\begin{array}{l}\text { Boot, Arnoud W.A., } \\
\text { Stuart I Greenbaum } \\
\text { and Anjan V. Thakor }\end{array}$ & Reputation and Discretion in Financial Contracting & 1993 \\
\hline $30 \mathrm{a}$ & Bergström, Reinhold & $\begin{array}{l}\text { The Full Tricotomous Scale Compared with Net Bal- } \\
\text { ances in Qualitative Business Survey Data - Experi- } \\
\text { ences from the Swedish Business Tendency Surveys }\end{array}$ & 1993 \\
\hline $30 \mathrm{~b}$ & Bergström, Reinhold & $\begin{array}{l}\text { Quantitative Production Series Compared with } \\
\text { Qualiative Business Survey Series for Five Sectors of } \\
\text { the Swedish Manufacturing Industry }\end{array}$ & 1993 \\
\hline 31 & $\begin{array}{l}\text { Lin, Chien-Fu Jeff and } \\
\text { Timo Teräsvirta }\end{array}$ & $\begin{array}{l}\text { Testing the Constancy of Regression Parameters } \\
\text { Against Continous Change }\end{array}$ & 1993 \\
\hline 32 & $\begin{array}{l}\text { Markowski, Aleksan- } \\
\text { der and Parameswar } \\
\text { Nandakumar }\end{array}$ & $\begin{array}{l}\text { A Long-Run Equilibrium Model for Sweden. The } \\
\text { Theory Behind the Long-Run Solution to the Econ- } \\
\text { ometric Model KOSMOS }\end{array}$ & 1993 \\
\hline 33 & $\begin{array}{l}\text { Markowski, Ale- } \\
\text { ksander and Tony } \\
\text { Persson }\end{array}$ & $\begin{array}{l}\text { Capital Rental Cost and the Adjustment for the Ef- } \\
\text { fects of the Investment Fund System in the Econo- } \\
\text { metric Model Kosmos }\end{array}$ & 1993 \\
\hline 34 & $\begin{array}{l}\text { Kanis, Alfred and } \\
\text { Bharat Barot }\end{array}$ & On Determinants of Private Consumption in Sweden & 1993 \\
\hline 35 & $\begin{array}{l}\text { Kääntä, Pekka and } \\
\text { Christer Tallbom }\end{array}$ & $\begin{array}{l}\text { Using Business Survey Data for Forecasting Swedish } \\
\text { Quantitative Business Cycle Varable. A Kalman Filter } \\
\text { Approach }\end{array}$ & 1993 \\
\hline 36 & $\begin{array}{l}\text { Ohlsson, Henry and } \\
\text { Anders Vredin }\end{array}$ & $\begin{array}{l}\text { Political Cycles and Cyclical Policies. A New Test } \\
\text { Approach Using Fiscal Forecasts }\end{array}$ & 1993 \\
\hline
\end{tabular}




\begin{tabular}{|c|c|c|c|}
\hline 37 & $\begin{array}{l}\text { Markowski, Aleksan- } \\
\text { der and Lars Ernsäter }\end{array}$ & $\begin{array}{l}\text { The Supply Side in the Econometric Model KOS- } \\
\text { MOS }\end{array}$ & 1994 \\
\hline 38 & $\begin{array}{l}\text { Gustafsson, Claes- } \\
\text { Håkan }\end{array}$ & $\begin{array}{l}\text { On the Consistency of Data on Production, Deliver- } \\
\text { ies, and Inventories in the Swedish Manufacturing } \\
\text { Industry }\end{array}$ & 1994 \\
\hline 39 & $\begin{array}{l}\text { Rahiala, Markku and } \\
\text { Tapani Kovalainen }\end{array}$ & $\begin{array}{l}\text { Modelling Wages Subject to Both Contracted Incre- } \\
\text { ments and Drift by Means of a Simultaneous- } \\
\text { Equations Model with Non-Standard Error Structure }\end{array}$ & 1994 \\
\hline 40 & $\begin{array}{l}\text { Öller, Lars-Erik and } \\
\text { Christer Tallbom }\end{array}$ & $\begin{array}{l}\text { Hybrid Indicators for the Swedish Economy Based on } \\
\text { Noisy Statistical Data and the Business Tendency } \\
\text { Survey }\end{array}$ & 1994 \\
\hline 41 & Östblom, Göran & $\begin{array}{l}\text { A Converging Triangularization Algorithm and the } \\
\text { Intertemporal Similarity of Production Structures }\end{array}$ & 1994 \\
\hline $42 \mathrm{a}$ & $\begin{array}{l}\text { Markowski, Aleksan- } \\
\text { der }\end{array}$ & $\begin{array}{l}\text { Labour Supply, Hours Worked and Unemployment in } \\
\text { the Econometric Model KOSMOS }\end{array}$ & 1994 \\
\hline $42 b$ & $\begin{array}{l}\text { Markowski, Aleksan- } \\
\text { der }\end{array}$ & $\begin{array}{l}\text { Wage Rate Determination in the Econometric Model } \\
\text { KOSMOS }\end{array}$ & 1994 \\
\hline 43 & $\begin{array}{l}\text { Ahlroth, Sofia, Anders } \\
\text { Björklund and Anders } \\
\text { Forslund }\end{array}$ & The Output of the Swedish Education Sector & 1994 \\
\hline $44 \mathrm{a}$ & $\begin{array}{l}\text { Markowski, Aleksan- } \\
\text { der }\end{array}$ & $\begin{array}{l}\text { Private Consumption Expenditure in the Econometric } \\
\text { Model KOSMOS }\end{array}$ & 1994 \\
\hline 44b & $\begin{array}{l}\text { Markowski, Aleksan- } \\
\text { der }\end{array}$ & $\begin{array}{l}\text { The Input-Output Core: Determination of Inventory } \\
\text { Investment and Other Business Output in the Econ- } \\
\text { ometric Model KOSMOS }\end{array}$ & 1994 \\
\hline 45 & Bergström, Reinhold & $\begin{array}{l}\text { The Accuracy of the Swedish National Budget Fore- } \\
\text { casts 1955-92 }\end{array}$ & 1995 \\
\hline 46 & Sjöö, Boo & $\begin{array}{l}\text { Dynamic Adjustment and Long-Run Economic Sta- } \\
\text { bility }\end{array}$ & 1995 \\
\hline $47 \mathrm{a}$ & $\begin{array}{l}\text { Markowski, Aleksan- } \\
\text { der }\end{array}$ & $\begin{array}{l}\text { Determination of the Effective Exchange Rate in the } \\
\text { Econometric Model KOSMOS }\end{array}$ & 1995 \\
\hline $47 \mathrm{~b}$ & $\begin{array}{l}\text { Markowski, Aleksan- } \\
\text { der }\end{array}$ & $\begin{array}{l}\text { Interest Rate Determination in the Econometric } \\
\text { Model KOSMOS }\end{array}$ & 1995 \\
\hline 48 & Barot, Bharat & $\begin{array}{l}\text { Estimating the Effects of Wealth, Interest Rates and } \\
\text { Unemployment on Private Consumption in Sweden }\end{array}$ & 1995 \\
\hline 49 & Lundvik, Petter & Generational Accounting in a Small Open Economy & 1996 \\
\hline 50 & $\begin{array}{l}\text { Eriksson, Kimmo, } \\
\text { Johan Karlander and } \\
\text { Lars-Erik Öller }\end{array}$ & Hierarchical Assignments: Stability and Fairness & 1996 \\
\hline 51 & Url, Thomas & Internationalists, Regionalists, or Eurocentrists & 1996 \\
\hline 52 & Ruist, Erik & Temporal Aggregation of an Econometric Equation & 1996 \\
\hline 53 & $\begin{array}{l}\text { Markowski, Aleksan- } \\
\text { der }\end{array}$ & $\begin{array}{l}\text { The Financial Block in the Econometric Model } \\
\text { KOSMOS }\end{array}$ & 1996 \\
\hline
\end{tabular}




\begin{tabular}{|c|c|c|c|}
\hline 54 & Östblom, Göran & $\begin{array}{l}\text { Emissions to the Air and the Allocation of GDP: } \\
\text { Medium Term Projections for Sweden. In Conflict } \\
\text { with the Goals of } \mathrm{SO}_{2}, \mathrm{SO}_{2} \text { and NOX Emissions for } \\
\text { Year } 2000\end{array}$ & 1996 \\
\hline 55 & $\begin{array}{l}\text { Koskinen, Lasse, } \\
\text { Aleksander } \\
\text { Markowski, Para- } \\
\text { meswar Nandakumar } \\
\text { and Lars-Erik Öller }\end{array}$ & Three Seminar Papers on Output Gap & 1997 \\
\hline 56 & $\begin{array}{l}\text { Oke, Timothy and } \\
\text { Lars-Erik Öller }\end{array}$ & Testing for Short Memory in a VARMA Process & 1997 \\
\hline 57 & $\begin{array}{l}\text { Johansson, Anders } \\
\text { and Karl-Markus } \\
\text { Modén }\end{array}$ & Investment Plan Revisions and Share Price Volatility & 1997 \\
\hline 58 & Lyhagen, Johan & $\begin{array}{l}\text { The Effect of Precautionary Saving on Consumption } \\
\text { in Sweden }\end{array}$ & 1998 \\
\hline 59 & $\begin{array}{l}\text { Koskinen, Lasse and } \\
\text { Lars-Erik Öller }\end{array}$ & $\begin{array}{l}\text { A Hidden Markov Model as a Dynamic Bayesian } \\
\text { Classifier, with an Application to Forecasting Busi- } \\
\text { ness-Cycle Turning Points }\end{array}$ & 1998 \\
\hline 60 & $\begin{array}{l}\text { Kragh, Börje and } \\
\text { Aleksander Markowski }\end{array}$ & $\begin{array}{l}\text { Kofi - a Macromodel of the Swedish Financial Mar- } \\
\text { kets }\end{array}$ & 1998 \\
\hline 61 & $\begin{array}{l}\text { Gajda, Jan B. and } \\
\text { Aleksander Markowski }\end{array}$ & $\begin{array}{l}\text { Model Evaluation Using Stochastic Simulations: The } \\
\text { Case of the Econometric Model KOSMOS }\end{array}$ & 1998 \\
\hline 62 & Johansson, Kerstin & Exports in the Econometric Model KOSMOS & 1998 \\
\hline 63 & Johansson, Kerstin & $\begin{array}{l}\text { Permanent Shocks and Spillovers: A Sectoral Ap- } \\
\text { proach Using a Structural VAR }\end{array}$ & 1998 \\
\hline 64 & $\begin{array}{l}\text { Öller, Lars-Erik and } \\
\text { Bharat Barot }\end{array}$ & Comparing the Accuracy of European GDP Forecasts & 1999 \\
\hline 65 & $\begin{array}{l}\text { Huhtala, Anni and } \\
\text { Eva Samakovlis }\end{array}$ & $\begin{array}{l}\text { Does International Harmonization of Environmental } \\
\text { Policy Instruments Make Economic Sense? The Case } \\
\text { of Paper Recycling in Europe }\end{array}$ & 1999 \\
\hline 66 & Nilsson, Charlotte & $\begin{array}{l}\text { A Unilateral Versus a Multilateral Carbon Dioxide } \\
\text { Tax - A Numerical Analysis With The European } \\
\text { Model GEM-E3 }\end{array}$ & 1999 \\
\hline 67 & $\begin{array}{l}\text { Braconier, Henrik and } \\
\text { Steinar Holden }\end{array}$ & $\begin{array}{l}\text { The Public Budget Balance - Fiscal Indicators and } \\
\text { Cyclical Sensitivity in the Nordic Countries }\end{array}$ & 1999 \\
\hline 68 & Nilsson, Kristian & $\begin{array}{l}\text { Alternative Measures of the Swedish Real Exchange } \\
\text { Rate }\end{array}$ & 1999 \\
\hline 69 & Östblom, Göran & $\begin{array}{l}\text { An Environmental Medium Term Economic Model - } \\
\text { EMEC }\end{array}$ & 1999 \\
\hline 70 & $\begin{array}{l}\text { Johnsson, Helena and } \\
\text { Peter Kaplan }\end{array}$ & $\begin{array}{l}\text { An Econometric Study of Private Consumption Ex- } \\
\text { penditure in Sweden }\end{array}$ & 1999 \\
\hline 71 & $\begin{array}{l}\text { Arai, Mahmood and } \\
\text { Fredrik Heyman }\end{array}$ & $\begin{array}{l}\text { Permanent and Temporary Labour: Job and Worker } \\
\text { Flows in Sweden 1989-1998 }\end{array}$ & 2000 \\
\hline
\end{tabular}




\begin{tabular}{|c|c|c|c|}
\hline 72 & $\begin{array}{l}\text { Öller, Lars-Erik and } \\
\text { Bharat Barot }\end{array}$ & $\begin{array}{l}\text { The Accuracy of European Growth and Inflation } \\
\text { Forecasts }\end{array}$ & 2000 \\
\hline 73 & Ahlroth, Sofia & $\begin{array}{l}\text { Correcting Net Domestic Product for Sulphur Diox- } \\
\text { ide and Nitrogen Oxide Emissions: Implementation } \\
\text { of a Theoretical Model in Practice }\end{array}$ & 2000 \\
\hline 74 & $\begin{array}{l}\text { Andersson, Michael } \\
\text { K. And Mikael P. } \\
\text { Gredenhoff }\end{array}$ & $\begin{array}{l}\text { Improving Fractional Integration Tests with Boot- } \\
\text { strap Distribution }\end{array}$ & 2000 \\
\hline 75 & $\begin{array}{l}\text { Nilsson, Charlotte and } \\
\text { Anni Huhtala }\end{array}$ & $\begin{array}{l}\text { Is } \mathrm{CO}_{2} \text { Trading Always Beneficial? A CGE-Model } \\
\text { Analysis on Secondary Environmental Benefits }\end{array}$ & 2000 \\
\hline 76 & Skånberg, Kristian & $\begin{array}{l}\text { Constructing a Partially Environmentally Adjusted } \\
\text { Net Domestic Product for Sweden } 1993 \text { and } 1997\end{array}$ & 2001 \\
\hline 77 & $\begin{array}{l}\text { Huhtala, Anni, Annie } \\
\text { Toppinen and Mattias } \\
\text { Boman, }\end{array}$ & $\begin{array}{l}\text { An Environmental Accountant's Dilemma: Are } \\
\text { Stumpage Prices Reliable Indicators of Resource Scar- } \\
\text { city? }\end{array}$ & 2001 \\
\hline 78 & Nilsson, Kristian & $\begin{array}{l}\text { Do Fundamentals Explain the Behavior of the Real } \\
\text { Effective Exchange Rate? }\end{array}$ & 2002 \\
\hline 79 & Bharat, Barot & $\begin{array}{l}\text { Growth and Business Cycles for the Swedish Econo- } \\
\text { my }\end{array}$ & 2002 \\
\hline 80 & Bharat, Barot & $\begin{array}{l}\text { House Prices and Housing Investment in Sweden and } \\
\text { the United Kingdom. Econometric Analysis for the } \\
\text { Period 1970-1998 }\end{array}$ & 2002 \\
\hline 81 & Hjelm, Göran & $\begin{array}{l}\text { Simultaneous Determination of NAIRU, Output } \\
\text { Gaps and Structural Budget Balances: Swedish Evi- } \\
\text { dence }\end{array}$ & 2003 \\
\hline 82 & $\begin{array}{l}\text { Huhtala, Anni and } \\
\text { Eva Samalkovis }\end{array}$ & Green Accounting, Air Pollution and Health & 2003 \\
\hline 83 & Lindström, Tomas & $\begin{array}{l}\text { The Role of High-Tech Capital Formation for Swe- } \\
\text { dish Productivity Growth }\end{array}$ & 2003 \\
\hline 84 & $\begin{array}{l}\text { Hansson, Jesper, Per } \\
\text { Jansson and Mårten } \\
\text { Löf }\end{array}$ & $\begin{array}{l}\text { Business survey data: do they help in forecasting the } \\
\text { macro economy? }\end{array}$ & 2003 \\
\hline 85 & $\begin{array}{l}\text { Boman, Mattias, Anni } \\
\text { Huhtala, Charlotte } \\
\text { Nilsson, Sofia Ahl- } \\
\text { roth, Göran Bostedt, } \\
\text { Leif Mattson and } \\
\text { Peichen Gong }\end{array}$ & $\begin{array}{l}\text { Applying the Contingent Valuation Method in Re- } \\
\text { source Accounting: A Bold Proposal }\end{array}$ & \\
\hline 86 & Gren, Ing-Marie & Monetary Green Accounting and Ecosystem Services & 2003 \\
\hline 87 & $\begin{array}{l}\text { Samakovlis, Eva, Anni } \\
\text { Huhtala, Tom Bellan- } \\
\text { der and Magnus Svart- } \\
\text { engren }\end{array}$ & $\begin{array}{l}\text { Air Quality and Morbidity: Concentration-response } \\
\text { Relationships for Sweden }\end{array}$ & 2004 \\
\hline 88 & $\begin{array}{l}\text { Alsterlind, Jan, Alek } \\
\text { Markowski and Kris- } \\
\text { tian Nilsson }\end{array}$ & $\begin{array}{l}\text { Modelling the Foreign Sector in a Macroeconometric } \\
\text { Model of Sweden }\end{array}$ & 2004 \\
\hline 89 & Lindén, Johan & The Labor Market in KIMOD & 2004 \\
\hline
\end{tabular}




\begin{tabular}{|c|c|c|c|}
\hline 90 & $\begin{array}{l}\text { Henrik Braconier, } \\
\text { Tomas Forsfält }\end{array}$ & $\begin{array}{l}\text { A New Method for Constructing a Cyclically Adjusted } \\
\text { Budget Balance: the Case of Sweden }\end{array}$ & 2004 \\
\hline 91 & $\begin{array}{l}\text { Hansen, Sten and } \\
\text { Tomas Lindström }\end{array}$ & Is Rising Returns to Scale a Figment of Poor Data? & 2004 \\
\hline 92 & Hjelm, Göran & $\begin{array}{l}\text { When Are Fiscal Contractions Successful? Lessons for } \\
\text { Countries Within and Outside the EMU }\end{array}$ & 2004 \\
\hline 93 & $\begin{array}{l}\text { Östblom, Göran and } \\
\text { Samakovlis, Eva }\end{array}$ & $\begin{array}{l}\text { Costs of Climate Policy when Pollution Affects } \\
\text { Health and Labour Productivity. A General } \\
\text { Equilibrium Analysis Applied to Sweden }\end{array}$ & 2004 \\
\hline 94 & $\begin{array}{l}\text { Forslund Johanna, } \\
\text { Eva Samakovlis and } \\
\text { Maria Vredin Johans- } \\
\text { son }\end{array}$ & $\begin{array}{l}\text { Matters Risk? The Allocation of Government Subsi- } \\
\text { dies for Remediation of Contaminated Sites under the } \\
\text { Local Investment Programme }\end{array}$ & 2006 \\
\hline 95 & $\begin{array}{l}\text { Erlandsson Mattias } \\
\text { and Alek Markowski }\end{array}$ & $\begin{array}{l}\text { The Effective Exchange Rate Index KIX - Theory } \\
\text { and Practice }\end{array}$ & 2006 \\
\hline 96 & $\begin{array}{l}\text { Östblom Göran and } \\
\text { Charlotte Berg }\end{array}$ & The EMEC model: Version 2.0 & 2006 \\
\hline 97 & $\begin{array}{l}\text { Hammar, Henrik, } \\
\text { Tommy Lundgren and } \\
\text { Magnus Sjöström }\end{array}$ & $\begin{array}{l}\text { The significance of transport costs in the Swedish } \\
\text { forest industry }\end{array}$ & 2006 \\
\hline 98 & Barot, Bharat & $\begin{array}{l}\text { Empirical Studies in Consumption, House Prices and } \\
\text { the Accuracy of European Growth and Inflation } \\
\text { Forecasts }\end{array}$ & 2006 \\
\hline 99 & Hjelm, Göran & $\begin{array}{l}\text { Kan arbetsmarknadens parter minska jämviktsarbets- } \\
\text { lösheten? Teori och modellsimuleringar }\end{array}$ & 2006 \\
\hline 100 & $\begin{array}{l}\text { Bergvall, Anders, To- } \\
\text { mas Forsfält, Göran } \\
\text { Hjelm, } \\
\text { Jonny Nilsson and } \\
\text { Juhana Vartiainen } \\
\end{array}$ & $\begin{array}{l}\text { KIMOD 1.0 Documentation of NIER's Dynamic } \\
\text { Macroeconomic General Equilibrium Model of the } \\
\text { Swedish Economy }\end{array}$ & 2007 \\
\hline 101 & Östblom, Göran & $\begin{array}{l}\text { Nitrogen and Sulphur Outcomes of a Carbon Emis- } \\
\text { sions Target Excluding Traded Allowances - } \\
\text { An Input-Output Analysis of the Swedish Case }\end{array}$ & 2007 \\
\hline 102 & $\begin{array}{l}\text { Hammar, Henrik and } \\
\text { Åsa Löfgren }\end{array}$ & $\begin{array}{l}\text { Explaining adoption of end of pipe solutions and } \\
\text { clean technologies - Determinants of firms' invest- } \\
\text { ments for reducing emissions to air in four sextors in } \\
\text { Sweden }\end{array}$ & 2007 \\
\hline 103 & $\begin{array}{l}\text { Östblom, Göran and } \\
\text { Henrik Hammar }\end{array}$ & $\begin{array}{l}\text { Outcomes of a Swedish Kilometre Tax. An Analysis } \\
\text { of Economic Effects and Effects on NOx Emissions }\end{array}$ & 2007 \\
\hline 104 & $\begin{array}{l}\text { Forsfält, Tomas, } \\
\text { Johnny Nilsson and } \\
\text { Juhana Vartianinen }\end{array}$ & $\begin{array}{l}\text { Modellansatser i Konjunkturinstitutets medel- } \\
\text { fristprognoser }\end{array}$ & 208 \\
\hline 105 & Samakovlis, Eva & $\begin{array}{l}\text { How are Green National Accounts Produced in Prac- } \\
\text { tice? }\end{array}$ & 2008 \\
\hline
\end{tabular}




\begin{tabular}{|c|c|c|c|}
\hline 106 & $\begin{array}{l}\text { Alek Markowski, Kris- } \\
\text { tian Nilsson, Marcus } \\
\text { Widén }\end{array}$ & $\begin{array}{l}\text { Strukturell utveckling av arbetskostnad och priser i } \\
\text { den svenska ekonomin }\end{array}$ & 2011 \\
\hline 107 & $\begin{array}{l}\text { Forslund, Johanna, } \\
\text { Per Johansson, Eva } \\
\text { Samakovlis and Maria } \\
\text { Vredin Johansson }\end{array}$ & $\begin{array}{l}\text { Can we by time? Evaluation. Evaluation of the } \\
\text { government's directed grant to remediation in Sweden }\end{array}$ & 2009 \\
\hline 108 & $\begin{array}{l}\text { Forslund, Johanna } \\
\text { Eva Samakovlis, Maria } \\
\text { Vredin Johansson and } \\
\text { Lars Barregård }\end{array}$ & $\begin{array}{l}\text { Does Remediation Save Lives? } \\
\text { On the Cost of Cleaning Up } \\
\text { Arsenic-Contaminated } \\
\text { Sites in Sweden }\end{array}$ & 2009 \\
\hline 109 & $\begin{array}{l}\text { Sjöström, Magnus and } \\
\text { Göran Östblom }\end{array}$ & $\begin{array}{l}\text { Future Waste Scenarios for Sweden on the Basis of a } \\
\text { CGE-model }\end{array}$ & 2009 \\
\hline 110 & Österholm, Pär & $\begin{array}{l}\text { The Effect on the Swedish Real Economy of the Fi- } \\
\text { nancial Crisis }\end{array}$ & 2009 \\
\hline 111 & Forsfält, Tomas & $\begin{array}{l}\text { KIMOD } 2.0 \text { Documentation of changes in the model } \\
\text { from January } 2007 \text { to January } 2009\end{array}$ & 2009 \\
\hline 112 & Österholm, Pär & $\begin{array}{l}\text { Improving Unemployment Rate Forecasts Using } \\
\text { Survey Data }\end{array}$ & 2009 \\
\hline 113 & Österholm, Pär & $\begin{array}{l}\text { Unemployment and Labour-Force } \\
\text { Participation in Sweden }\end{array}$ & 2009 \\
\hline 114 & $\begin{array}{l}\text { Jonsson, Thomas and } \\
\text { Pär Österholm }\end{array}$ & $\begin{array}{l}\text { The Properties of Survey-Based } \\
\text { Inflation Expectations in Sweden }\end{array}$ & 2009 \\
\hline 115 & $\begin{array}{l}\text { Hjelm, Göran and } \\
\text { Kristian Jönsson }\end{array}$ & $\begin{array}{l}\text { In Search of a Method for Measuring the Output Gap } \\
\text { of the Swedish Economy }\end{array}$ & 2010 \\
\hline 116 & Vartiainen, Juhana & Interpreting Wage Bargaining Norms & 2010 \\
\hline 117 & $\begin{array}{l}\text { Mossfeldt, Marcus and } \\
\text { Pär Österholm }\end{array}$ & $\begin{array}{l}\text { The Persistent Labour-Market Effects of the Financial } \\
\text { Crisis }\end{array}$ & 2010 \\
\hline 118 & $\begin{array}{l}\text { Östblom, Göran, Ma- } \\
\text { ria Ljunggren Söder- } \\
\text { man and Magnus Sjö- } \\
\text { ström }\end{array}$ & $\begin{array}{l}\text { Analysing future solid waste generation - Soft linking } \\
\text { a model of waste management with a CGE-model for } \\
\text { Sweden }\end{array}$ & 2010 \\
\hline 119 & $\begin{array}{l}\text { Broberg, Thomas, } \\
\text { Per-Olov Marklund, } \\
\text { Eva Samakovlisa and } \\
\text { Henrik Hammar }\end{array}$ & $\begin{array}{l}\text { Does environmental leadership pay off for Swed-ish } \\
\text { industry? - Analyzing the effects of environ-mental } \\
\text { investments on efficiency }\end{array}$ & 2010 \\
\hline 120 & $\begin{array}{l}\text { Gustavsson, Magnus } \\
\text { and Pär Österholm }\end{array}$ & $\begin{array}{l}\text { Labor-Force Participation Rates and the } \\
\text { Informational Value of Unemployment Rates: Evi- } \\
\text { dence from Disaggregated US Data }\end{array}$ & 2010 \\
\hline 121 & $\begin{array}{l}\text { Jonsson, Thomas and } \\
\text { Pär österholm }\end{array}$ & $\begin{array}{l}\text { The Forecasting Properties of Survey-Based Wage- } \\
\text { Growth Expectations }\end{array}$ & 2010 \\
\hline 123 & $\begin{array}{l}\text { Broberg, Thomas, } \\
\text { Tomas Forsfält and } \\
\text { Göran Östblom }\end{array}$ & $\begin{array}{l}\text { The Excess Cost of Supplementary Constraints in } \\
\text { Climate Policy: The Case of Sweden's Energy Intensi- } \\
\text { ty Target }\end{array}$ & 2011 \\
\hline
\end{tabular}




\begin{tabular}{|l|l|l|l|}
\hline 124 & $\begin{array}{l}\text { Patrik Baard, Henrik } \\
\text { Carlsen, Karin Ed- } \\
\text { vardsson Björnberg } \\
\text { and Maria Vredin } \\
\text { Johansson }\end{array}$ & $\begin{array}{l}\text { Scenarios and Sustainability. A Swedish Case Study of } \\
\text { Adaptation Tools for Local Decision-Makers }\end{array}$ & 2011 \\
\hline 125 & $\begin{array}{l}\text { Hansson, Sven Ove, } \\
\text { Karin Edvardsson } \\
\text { Björnberg and } \\
\text { Maria Vredin Johans- } \\
\text { son }\end{array}$ & $\begin{array}{l}\text { Making Climate Policy Efficient } \\
\text { Implementing a Model for Environmental Policy } \\
\text { Efficiency }\end{array}$ & 2011 \\
\hline 126 & $\begin{array}{l}\text { Antipin, Jan-Erik, } \\
\text { Farid Jimmy Boume- } \\
\text { diene and Pär Öster- } \\
\text { holm }\end{array}$ & $\begin{array}{l}\text { Forecasting Inflation Using Constant Gain Least } \\
\text { Squares }\end{array}$ & 2012 \\
\hline 127 & $\begin{array}{l}\text { Meredith Beechey, Pär } \\
\text { Österholm }\end{array}$ & $\begin{array}{l}\text { Policy Interest Rate Expectations in Sweden: A Fore- } \\
\text { cast Evaluation }\end{array}$ & 2012 \\
\hline 128 & $\begin{array}{l}\text { Meredith Beechey, Pär } \\
\text { Österholm }\end{array}$ & $\begin{array}{l}\text { Central Bank Forecasts of Policy Interest Rates: An } \\
\text { Evaluation of the First Years }\end{array}$ & 2013 \\
\hline 129 & $\begin{array}{l}\text { Jan-Erik Antipin, } \\
\text { Farid Jimmy Boume- } \\
\text { diene, Pär Österholm }\end{array}$ & $\begin{array}{l}\text { On the Usefulness of Constant Gain Least Squares } \\
\text { when Forecasting the Unemployment Rate }\end{array}$ & 2013 \\
\hline
\end{tabular}



National Institute of Economic Research, Kungsgatan 12-14, Box 3116, SE-103 62 Stockholm, Sweden Phone: +46 845359 00, Fax: +46 845359 80, E-mail: ki@konj.se, Website: www.konj.se

ISSN $1100-7818$ 